\title{
The Dynamics in Swedish House Prices - An Empirical Time Series Analysis
}

\author{
Lennart Berg
}

Johan Lyhagen

Januari 1998 


\section{Arbetsrapport/Working Paper}

1. Patric H. Hendershott and Bengt Turner, Estimating Capitalization Rates and Capitalization Effects in Stockholm.

2. Robert A Murdie and Lars-Eric Borgegård, Immigration, Spatial Segregation and Housing Segmentation in Metropolitan Stockholm, 1960-95.

3. Jim Kemeny, Social Markets in European Rental Housing.

4. Jim Kemeny and Ceri Llewellyn-Wilson, Both Rationed and Subsidised. Jersey's command economy in housing.

5. Terry Hartig, Florian G. Kaiser \& Peter A. Bowler, Further development of a measure of perceived environmental restorativeness.

6. Bo Bengtsson, K A Stefan Svensson \& Cathrine Uggla, Hyresgästens dilemma. Samarbetsnormer och kollektivt handlande i bostadsområden.

7. Patric H. Hendershott and Bengt Turner, A New Look at Capitalization Rates and Capitalization Effects for Apartments and Commercial Properties: Evidence from Stockholm. This Working Paper replaces Working Paper No. 1.

8. Gärd Folkesdotter och Inga Michaeli (red).), Samhällsbygget och samhällsväven.

9. Eva Sandstedt, Susanna Fork, Kerstin Jacobsson, Nader Ahmadi och Elisabeth Lindberg, Förorten i ett senmodernt planeringsperspektiv.

10. Inga Michaeli, Mellan vardagsliv och lokal administration - En studie av miljöarbetet i Borlänge kommun.

11. Eva Sandstedt, Allergi och sjuka hussymptom i skolan. Att hantera risker.

12. Lennart Berg and Johan Lyhagen, The Dynamics in Swedish House Prices - An Empirical Time Series Analysis. 


\title{
Småhuspriser på andrahandsmarknaden i storstadsregioner och andra regioner under 1980- och 1990-talet - samvariation, påverkan och bestämningsfaktorer
}

\author{
Lennart Berg $\bowtie$
}

\begin{abstract}
Abstrakt. I uppsatsen analyseras utvecklingen av småhuspriserna på andrahandsmarknaden för perioden januari 1981 till juli 1997 för tre storstadsregioner och fyra s k LAregioner. Relativa reala prisutvecklingen för samtliga regioner uppvisar stark egenprisdynamik och korreleogrammen för autokorrelationen för dessa variabler överensstämmer med ett mönster som är förenligt med mean reverting och långt minne. Grangertest indikerar att relativa reala prisutvecklingen för Stockholmsregionen har informationsinnehåll för alla de övrig regionerna med en tidseftersläpning på upp till ett år. Stockholmsregionen förefaller entydigt "leda" prisutvecklingen på småhusmarknaden, en effekt som överensstämmer med den effekt Londonregionen har på den brittiska småhusmarknaden. - Bivariata och multivariata Granger test mellan reala prisutvecklingen i Stockholmsregionen och ett antal reala och finansiella makrovariabler visar att dess variabler hade informationsinnehåll. Därvid var realränta efter skatt, terminspremien, utvecklingen på aktiemarknaden, industriproduktionen samt en "proxy-variabel" för konsumtionsutvecklingen viktiga faktorer. En enkel VAR-modell med real prisutveckling i Stockholmsregionen, "konsumtionsproxyn" och förändring i arbetslöshet som endogen variabler och ett antal exogena variabler har estimerats. Experiment med impuls-respons funktioner indikerar bl a att en chock i arbetslösheten ger en kraftig påverkar i utvecklingen av huspriser och konsumtionen och att anpassningen mot en ny jämvikt tar 4-5 år.
\end{abstract}

\footnotetext{
$\triangle$ Institutet för byggnadsforskning och Nationalekonomiska institutionen vid Uppsala universitet. E-mail lennart.berg@nek.uu.se.
} 


\section{Inledning}

Välkänt är att under 1980- och 1990-talet har den ekonomiska utvecklingen i Sverige kännetecknats av kraftiga svängningar och att påstå att denna utveckling har varit volatil är knappast någon överdrift. Senare delen av 1980-talet och början på 1990-talet utmärktes av bl a en stark löneutveckling och konsumtionstillväxt, negativa realräntor efter skatt för de flesta hushåll, hög real förändring i tillgångspriser (aktier, bostads- och kommersiella fastigheter, småhus, fritidsfastigheter $\mathrm{m} \mathrm{m}$ ), hög inflation och rekordlåg arbetslöshet. Några år in på 1990-talet hade utvecklingen av dessa variabler helt förbyts; många av dem uppvisade en teckenförändring och för vissa variabler var det absoluta beloppet konstant. Bakom denna s k boom-to-bust cycle döljer sig bl a den ekonomiska överhettningen i slutet av 1980-talet, skattereformen och realräntechocken i början på 1990-talet.

Priserna på andrahandsmarknaden för småhus minskade, realt sett för hela riket, med ca 25 procent mellan 1981 och 1985 . Perioden därefter fram till mitten av 1991 kännetecknades däremot av reala prishöjningar på bortemot 40 procent. Från den högsta prisnivån föll realpriset med 25 procent fram till mitten av 1996. Sedan 1996 har marknaden återhämtat sig och fram till i början av 1998 har noterats en ökning av realpriset med ca 10 procent. Från 1982 till juli 1997 har endast Stockholmsregionen haft genomsnittligt sett, en real utveckling av småhuspriserna med ca 0,7 procent medan alla övriga regioner som analyseras i denna uppsats har haft negativ utveckling.

De redovisade svängningarna i huspriserna har resulterat i kraftiga kapitaliseringseffekter. Beräknas reala värdeförändringen i hushållens innehav av små- och fritidshus minskade värdet av dessa med ca 40000 kr per invånare mellan 1982 och 1986, ökade därefter med $60000 \mathrm{kr}$ fram till 1991 för att sedan falla med hela 85000 kr fram till 1996. Av stort intresse är naturligtvis om dessa värdeförändringar påverkar övriga delar av ekonomin. Cirka 1/3 av hushållens förmögenhet utgörs av värdet på småhusfastigheterna och en intressant fråga är om kapitalvinster och -förluster för dessa fastigheter påverkar konsumtionen och sparandet. Ett sätt att illustrera hur hushållens förmögenhet, sparande och konsumtion hänger samman, är att utgå ifrån hushållens balansräkning. En värdeförändring i hushållens förmögenhet påverkar hushållens soliditet eller skuldkvot. Utgår vi ifrån att hushållen vill hålla en viss nivå på sin soliditet betyder en ökning (minskning) av huspriserna, ceteris paribus, att sparandet minskar (ökar) när portfölj- 
jämvikten återställs. Ett flertal empiriska studier visar också att huspriser och värdet av hushållens fastighetsinnehav påverkar konsumtion och sparande. ${ }^{1}$

Vid empiriska analyser av prisutvecklingen av andrahandsmarknaden för småhus har såväl svenska som utländska studier rapporterat förekomsten av en kraftig egenprisdynamik. ${ }^{2}$ Förekomsten av egenprisdynamik strider mot utsagan från den $\mathrm{s} \mathrm{k}$ effektiva marknadshypotesen om informationseffektivitet. Innebörden av den effektiva marknadshypotesen är bl a att all tillgänglig information redan har diskonterats eller inkorporerats i priserna och tidigare perioders relativa prisförändringar skall således inte kunna användas för att prediktera dagens prisförändring. ${ }^{3}$

En alternativ modell som ofta diskuteras baseras på Poterbas (1984) s k asset market model. En utsaga från denna modell är att en chock på marknaden kommer att ge upphov till att beståndet av hus anpassas och i och med att vi har att göra med ett bestånd av hus (stock) blir detta en utdragen process. Som en följd av detta kommer den relativa förändringen i huspriserna att över tiden först uppvisa negativ korrelation och sedan positiv. Autokorrelationen för den relativa förändringen i huspriserna uppvisar ett mönster som indikerar att prisnivån kommer tillbaka till sin ursprungliga nivå. Denna typ av autokorrelationsprocesser brukar benämnas mean reverting. En kraftig förekomst av egenprisdynamik är förenlig med mean reverting i autokorrelationsprocessen och därmed med Poterba modellen.

Utvecklingen av småhuspriserna på andrahandsmarknaden är ett centralt område för ekonomer att studera. Kunskap om vad som driver utvecklingen på denna marknad är eftertraktad information för såväl finansministern och riksbankschefen som fastighetsmäklare! Vi analyserar två frågeställningar i denna uppsats, nämligen:

* För det första analyseras prisutvecklingen för andrahandsmarknaden för småhus på såväl regional som aggregerad nivå för 1980- och 1990-talet. Frågeställningen är då om någon eller några regioner leder prisutvecklingen, dvs om prisimpulser från någon region påverkar och dominerar de andra. I detta sammanhang används s k kausalitetstest för att studera informationsinnehållet i prisutvecklingen emellan de valda regionerna. Dessa test ger en indikation på om prisutvecklingen i en region påverkar var och en av de andra regioner.

\footnotetext{
${ }^{1}$ Se Brodin and Nymoen (1992) för Norge, Koskela et al för Finland, Bayoumi (1993) för England och Berg and Bergström (1995) samt Ekman (1997) för Sverige. För en översikt över de nordiska länderna se Berg(1994).

${ }^{2}$ Se Englund och Ioannides (1997) för en analys av huspriser i 15 OECD-länder, Cho (1996) för en översikt av amerikanska studier, Muellbauer och Murphy (1997) för en analys av brittiska marknaden och Hort (1997) samt Berg och Lyhagen (1998) för analyser av den svenska marknaden.

${ }^{3}$ Se t ex Campell m fl (1997) för en översikt av effektiva marknadshypotesen och olika statistiska test i detta sammanhang.
} 
* För det andra analyseras och diskuteras hur olika finansiella och reala makrovariabler är relaterade till utvecklingen av huspriser. Denna analys sker också med kausalitetstest men i detta fall utökas analysen till att även omfatta s k multivariata Granger test. Experiment kommer också göras med en vektorautoregressiva modell (VARmodel-ler) för att studera bl a anpassningstiden i huspriserna utifrån chocker eller innovationer i olika variabler. Vi utgår då från en modell bestående av tre endogena variabler, varav en är en relativa förändringen i huspriser, och studerar hur dessa påverkas av varandra och andra makrovariabler. När VAR-modellen specificeras diskuteras kortfattat teoretiska motiveringar bakom valet av variabler.

Analysen baseras på månadsdata och data för huspriser har grupperats i tre storstadsområde och i fyra s k lokala arbetsmarknadsregioner (LA-regioner), nämligen medelstora och små kommuner samt industri- och glesbygdskommuner. ${ }^{4}$ I analysen utnyttjas finansiella och reala makrovariabler som bl a industriproduktionsindex, nybilsregistreringen, arbetslöshet, kort och lång realränta efter skatt, terminspremien, börsindex och olika likviditetsmått.

Denna typ av analys har tidigare inte gjorts för svenska förhållanden men har publicerats för andra länder. Ett exempel på en sådan studie för den amerikanska småhusmarknaden är Pollakowski och Ray (1997) och som finner att prischocker i småhuspriserna sprids över de regioner som studeras.

\section{Beskrivning av data}

Data omfattar uppgifter från januari 1981 till augusti 1997 för samtliga försäljningar av småhus i Sverige. Från dessa data, omfattande drygt 830000 observationer, har materialet delats in i tre storstadsregioner och fyra LA regioner på månadsbasis. Storstadsregionerna utgörs av Stockholm, Göteborg och Malmö. De fyra LA regionerna är som nämnts medelstora och små kommuner samt industri- och glesbygdskommuner. För att beräkna ett prisindex på månadsbasis, det s k vägda K/T talet, divideras summan av försäljningspriserna med summan av taxeringsvärdena på månadsbasis för varje region. ${ }^{5} \mathrm{I}$ och med att småhusen omtaxerades under slutet av 1980- och mitten av 1990-talet och nya taxeringsvärden åsattes fastigheterna per den första januari 1990 respektive 1996, har prisnivån för de sju regionerna justerats så att dessa blir jämförbara för hela tidsperioden.

Figur 1 Utveckling av nominell prisnivå och antal månadsvisa försäljningar av småhus (vänster respektive höger skala i första figuren) samt real prisnivå

\footnotetext{
${ }^{4}$ Datasetet har ställts samman av Tommy Berger och författaren är skyldig honom ett stort tack för detta.

${ }^{5}$ F o m 1995 ersätts taxeringsvärdena med s k basvärden.
} 
och relativ real prisförändring på årsbasis (vänster respektive höger skala $i$ andra figuren), månadsdata 1981:1-97:7 totalt för hela riket
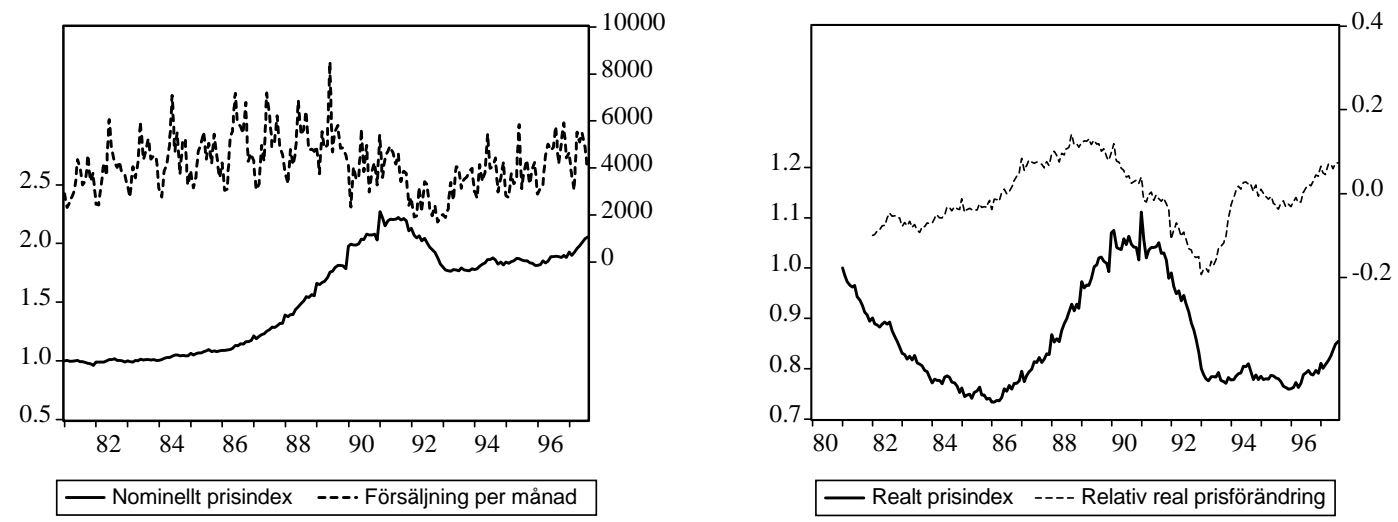

För att få en överblick över prisutvecklingen för småhus totalt för hela riket och i de valda regionerna redovisas inledningsvis fyra grafer och två tabeller med data och statistiska uppgifter. Denna redovisning bör ge en indikation om bl a prisutvecklingen i de olika regionerna. I Figur 1 redovisas i den första grafen prisindex för hela riket i löpande pris samt genomsnittliga försäljningar per månad. Januari 1981 har valts som basår för det nominella prisindexet och från detta år var index i stort oförändrat till några år in på 1980-talet och ökade sedan fr o m 1985. För januari 1991 noterades det högsta värdet för den nominella prisnivån, 2,27. Efter denna högsta notering faller priserna och index noteras till 2,05 för den sista observationen i augusti 1997. I samma graf går det också att följa de månadsvisa försäljningarna. För hela perioden var medelvärdet för antalet försäljningar drygt 4000 (se även Tabell 1) och i grafen framkommer att det sannolikt finns en säsongskomponent i tidsserien över de månadsvisa försäljningarna. Enkel "ögonekonometri” indikerar också att det tycks föreligga en positiv korrelation mellan prisindex och antalet försäljningar; överlåtelserna var fler under slutet av 1980-talet när priserna ökade och överlåtelserna minskade vid det nominella prisfallet efter 1991.

Om den reala prisutvecklingen studeras erhålls en annan bild jämfört med den utveckling som det nominella indexet uppvisar. I den andra grafen i Figur 1 återges den reala prisnivåns utveckling tillsammans med den relativa årliga reala prisutvecklingen. ${ }^{6}$ Det reala prisindexet har framräknats genom att dividera det nominella indexet med konsumentprisindex. Skillnaden mellan de två prisserierna sammanhänger således med den allmänna prisutvecklingen. Redan i inledningen till denna uppsats har utveckling av det reala priset för småhus diskuterats och vi koncentrerar oss här på att studera den relativa reala prisförändringen. Den relativa förändringen blir naturligtvis negativ när det reala

\footnotetext{
${ }^{6}$ Genomgående när relativa prisförändringar för huspriser analyseras utgår vi ifrån att prisnivån har ett s $\mathrm{k}$ stokastiskt säsongsmönster i och med att vi arbetar med årsdifferenser på logaritmen av prisnivån. Detta betyder att när relativa förändringen i en variabel genereras skrivs den som $\Delta_{12} y=\ln P_{\mathrm{t}}-\ln P_{\mathrm{t}-12}$, där $P$ representera prisnivån. Vi har också testat huruvida det finns något deterministiskt säsongsmönster i de genererade relativa prisförändringarna och fann att så inte var fallet.
} 
prisindexet uppvisar en negativ lutning och vice versa. Det framgår med all önskvärd tydlighet av grafen att den relativa reala prisförändringen var negativ t o m 1985 och under perioden 1991-94. Övriga perioder var den positiv. Påpekas bör att den relativa reala prisförändringen har framräknats på årsbasis (säsongsdifferenser).

För att åskådliggöra hur de valda sju regionerna samvarierar presenteras för respektive region dels ett nominellt prisindex, dels den relativa reala prisförändringen. Detta återges i Figur 2 men innan regionernas priser och prisförändringar diskuteras kan det vara på sin plats att redovisa antalet omsatta småhusfastigheter i de olika regionerna. Medelvärden, min- och max-värden samt standardavvikelse och variationskoefficient för antalet försäljningar presenteras i Tabell 1 och av denna framgår att småkommunerna hade det högsta medelvärdet, glesbygd det lägsta och industrikommuner det näst lägsta. Stockholmsregionen och medelstora kommuner har uppvisade ungefär samma medelvärde beträffande omsättning medan medelvärdet för Göteborgsregionen var större än för Malmöregionen. Av tabellen framgår också att variationskoefficienten (kvoten mellan standardavvikelse och medelvärde) i stort sett var lika stor eller liten för de fem första indelningarna, högre för industrikommuner och högst för glesbygdskommuner.

Tabell 1 Månatliga medelvärden och annan statistisk redovisning för antalet försäljningar för storstadsregionerna och de fyra övriga regionindelningarna för perioden 1981:1-97:7

\begin{tabular}{lcccccccc}
\hline & $\begin{array}{c}\text { Stock- } \\
\text { holm }\end{array}$ & $\begin{array}{c}\text { Göte- } \\
\text { borg }\end{array}$ & Malmö & $\begin{array}{c}\text { Medel- } \\
\text { stora }\end{array}$ & Små & Industri & $\begin{array}{c}\text { Gles- } \\
\text { bygd }\end{array}$ & Samtliga \\
Medelvärde & 600 & 370 & 325 & 620 & 1863 & 230 & 155 & 4163 \\
Max & 1084 & 756 & 655 & 1298 & 3951 & 521 & 432 & 8513 \\
Min & 260 & 110 & 139 & 253 & 748 & 86 & 54 & 1689 \\
Standardavvikelse & 175 & 109 & 93 & 184 & 547 & 76 & 57 & 1160 \\
Variationskoefficient & 0,29 & 0,29 & 0,28 & 0,30 & 0,29 & 0,33 & 0,37 & 0,28 \\
\hline
\end{tabular}

Som framgår av de två graferna i Figur 2 fanns det en viss spridning mellan regionerna beträffande såväl den nominella prisnivån som den relativa reala prisförändringen. Storstadsregionerna hade den högsta nivån för såväl nominellt index som för relativ real prisförändring medan industrikommunerna uppvisade den lägsta nivån för den nominella prisnivån. Den horisontella skalan för den nominella prisnivån i Figur 2 är logaritmisk vilket innebär att lutningen på de olika regionernas prisindex representerar tillväxten i de nominella priserna. För att få en uppfattning om spridningarna i den relativa reala prisförändringen har tre olika förändringstal framräknats för varje region, se Tabell 2. Utöver relativ nominell och reala prisförändring finns även en variabel som benämns Excess return. Den sistnämnda variabeln har beräknats som relativ nominell prisförändring minus ränta efter skatt. Denna variabel har medtagits i analysen för att få en upp- 
fattning om huruvida småhusen har genererat någon överavkastning eller riskpremie för den undersökta perioden.

Figur 2 Utveckling av nominell prisnivå (vänstra figuren och logaritmisk skala på horisontala axeln) och relativ reala prisförändring (årsbasis) för storstadsregionerna och de fyra övriga regionindelningarna för perioden 1981:1$97: 7$
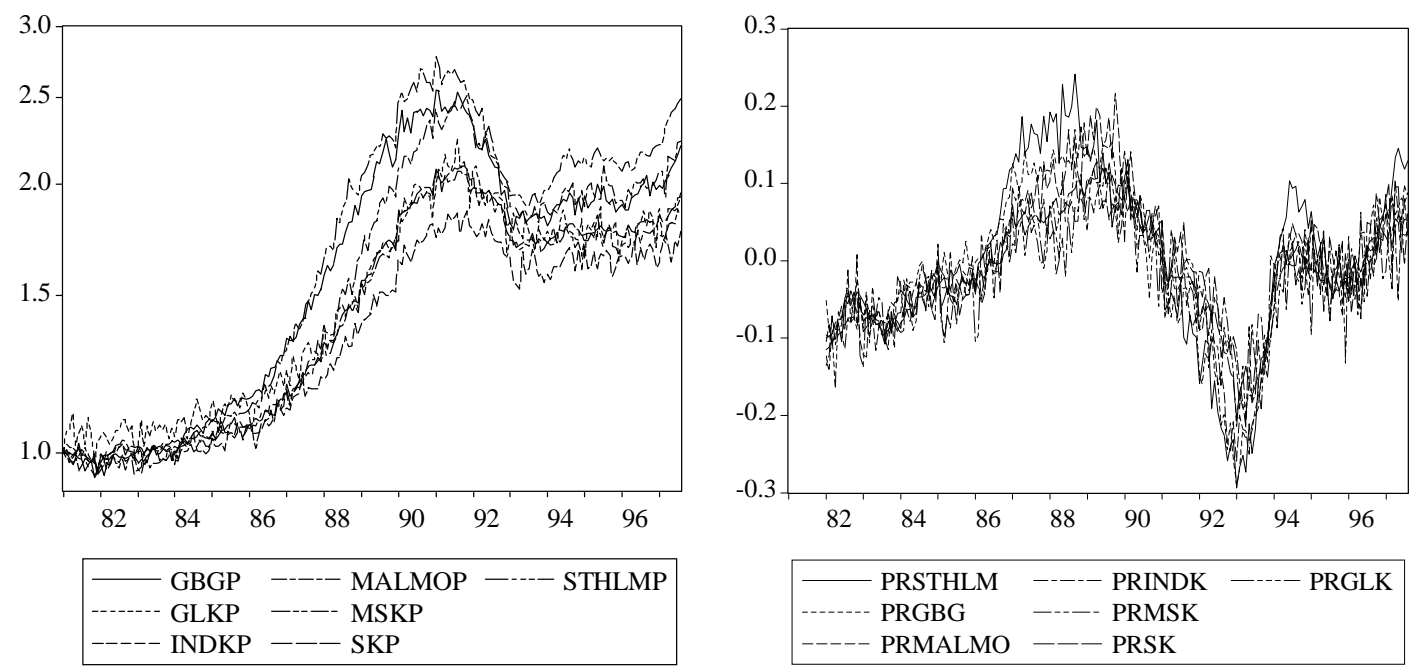

Stockholmsregionen uppvisade såväl de högsta medelvärdena som standardavvikelser för de tre variabler. Observera också att endast denna region uppvisar positiva medelvärden för relativ real avkastning och excess return. För övriga regioner var medelvärdena för dessa två variabler negativa och i ett fall lika med noll. Att Stockholmsregion hade den största spridningen indikeras också av min- och max-värdena i Tabell 2. I tabellen finns också rapporterat statistiska test för huruvida de tre avkastningsvariablerna är normalfördelade och denna nollhypotes kan inte förkastas för någon av variabler i någon region. 
Tabell 2 Redovisning av medelvärde, min- och max-värden, standardavvikelse, normalfördelnings- och enhetsrotstest för relativ nominell och reala prisförändring (årsbasis) samt excess return (relativ nominell prisförändring minus ränta efter skatt) för storstadsregionerna och de fyra övriga regionindelningarna för perioden 1981:1-97:7

\begin{tabular}{|c|c|c|c|c|c|c|c|}
\hline & Mean & Max & Min & Std dev & $\mathrm{JB}$ & $\mathrm{DF}(8)$ & $\mathrm{PP}(8)$ \\
\hline \multicolumn{8}{|l|}{ Stockholm } \\
\hline Nominal & 0.061 & 0.344 & -0.220 & 0.119 & 0.90 & -1.98 & $-1.45^{* *}$ \\
\hline Real & 0.007 & 0.273 & -0.255 & 0.112 & 0.49 & -2.27 & $-1.81 *$ \\
\hline Excess return & 0.003 & 0.293 & -0.324 & 0.125 & 0.60 & -2.31 & $-1.76^{*}$ \\
\hline \multicolumn{8}{|l|}{ Göteborg } \\
\hline$\underline{\text { Nominal }}$ & 0.054 & 0.260 & -0.217 & 0.103 & 0.18 & $-1.54 * *$ & $-1.46 * *$ \\
\hline Real & -0.001 & 0.192 & -0.252 & 0.095 & 0.36 & $-1.85 *$ & -2.03 \\
\hline Excess return & -0.005 & 0.208 & -0.302 & 0.109 & 0.02 & -1.94 & $-1.81 *$ \\
\hline \multicolumn{8}{|l|}{$\underline{\text { Malmö }}$} \\
\hline Nominal & 0.055 & 0.321 & -0.208 & 0.106 & 0.81 & $-1.87 *$ & $-1.78^{*}$ \\
\hline Real & 0.000 & 0.241 & -0.228 & 0.095 & 0.92 & -2.37 & -2.37 \\
\hline Excess return & -0.004 & 0.260 & -0.295 & 0.110 & 0.69 & -2.28 & -2.18 \\
\hline \multicolumn{8}{|l|}{ Medelstora } \\
\hline Nominal & 0.041 & 0.206 & -0.145 & 0.078 & 0.39 & $-1.40 * *$ & $-1.79 *$ \\
\hline Real & -0.012 & 0.139 & -0.186 & 0.068 & 0.40 & $-1.77 *$ & -2.61 \\
\hline Excess return & -0.017 & 0.150 & -0.222 & 0.080 & 0.78 & $-1.69 *$ & -2.15 \\
\hline \multicolumn{8}{|l|}{ Industri } \\
\hline Nominal & 0.037 & 0.200 & -0.154 & 0.068 & 0.64 & $-1.29 * *$ & -3.47 \\
\hline Real & -0.016 & 0.119 & -0.195 & 0.061 & 0.36 & -1.96 & -4.38 \\
\hline Excess return & -0.022 & 0.131 & -0.220 & 0.070 & 0.78 & $-1.74^{*}$ & -3.98 \\
\hline \multicolumn{8}{|l|}{ Små } \\
\hline Nominal & 0.043 & 0.201 & -0.147 & 0.077 & 0.90 & -1.91 & $-1.29 *$ \\
\hline Real & -0.011 & 0.127 & -0.185 & 0.069 & 0.35 & -2.26 & -1.95 \\
\hline Excess return & -0.015 & 0.140 & -0.232 & 0.081 & 0.45 & -2.41 & $-1.69 *$ \\
\hline \multicolumn{8}{|l|}{ Glesbygd } \\
\hline Nominal & 0.040 & 0.214 & -0.155 & 0.080 & 0.57 & $-1.34 * *$ & -4.39 \\
\hline Real & -0.014 & 0.137 & -0.193 & 0.071 & 0.24 & $-1.71 *$ & -5.81 \\
\hline Excess return & -0.019 & 0.150 & -0.226 & 0.083 & 0.38 & $-1.87 *$ & -4.66 \\
\hline \multicolumn{8}{|c|}{ Totalt hela riket } \\
\hline Nominal & 0.047 & 0.211 & -0.155 & 0.084 & 0.72 & -2.03 & $-1.27 * *$ \\
\hline Real & -0.007 & 0.142 & -0.193 & 0.076 & 0.26 & -2.35 & $-1.81^{*}$ \\
\hline Excess return & -0.011 & 0.154 & -0.255 & 0.089 & 0.14 & -2.66 & $-1.66 * *$ \\
\hline
\end{tabular}

Resultatet för Jarque-Bera statistiska normalfördelnings test, JB, ges som s k p-värde; ett värde större än 0,05 indikerar att nollhypotesen om normalfördelning inte kan förkastas på 5 procents nivån. Kritiska värden för testen för enhetsrot, Dickey-Fuller respektive Phillips-Peron, på 1 procents nivå -2.58 , på 5 procents nivå -1.90 och på 10 procents nivå -1.62 . Dickey-Fuller testet är utfört utan konstant och trend och med åtta differenser av prisförändringarna. Phillips-Peron är utfört utan konstant och med en trunkeringslag på åtta perioder. * efter den redovisade teststatistikan indikerar att nollhypotesen om ingen enhetsrot inte kan förkastas på 5 procents nivå men väl på 10 procents nivå. ** att nollhypotesen inte kan förkastas på 10 procents nivån.

Slutligen finns test av enhetsrot, unit root test, i variablerna rapporterat i Tabell 2. Huruvida en tidsserie är stationär eller icke-stationär (tidsserien uppvisar en enhetsrot) är viktigt att veta på innan en statistisk analys utförs. Analyseras en tidsserie $\mathrm{m} \mathrm{h}$ a en integrerad autoregressiv och glidande medelvärdes model, en s k ARMA- 
modell, krävs att tidsserien i fråga är stationär. Används icke-stationära variabler i regressionsanalys blir många av standardtesten för denna analys inte giltiga. De test för förekomst av icke-stationäritet som rapporteras är Dickey-Fuller (utan konstant och trend och med åtta differenser av prisförändringarna) och Phillips-Peron testet (utan konstant och med en trunkeringslag på åtta perioder) och under tabellen ges de kritiska värdena för signifikans. Resultaten tyder på att för flertalet av tidsserierna kan vi förkasta nollhypotesen om icke-stationäritet på 5 procents nivån och lägre nivå. Endast i ett fall, relativ nominell prisförändring för Göteborgsregionen, indikerar båda testen att nollhypotesen inte kan förkastas. För den relativa reala prisförändringen, som fortsättningsvis kommer att analyseras, indikerar testen att nollhypotesen om icke-stationäritet genomgående kan förkastas för endera av de två testen.

Figur 3 Autokorrelation och partiell autokorrelation för reala relativa prisförändringar för småhus upp till 86 månader för hela riket (vänstra kolumnen) och Stockholmsregionen (högra kolumnen)
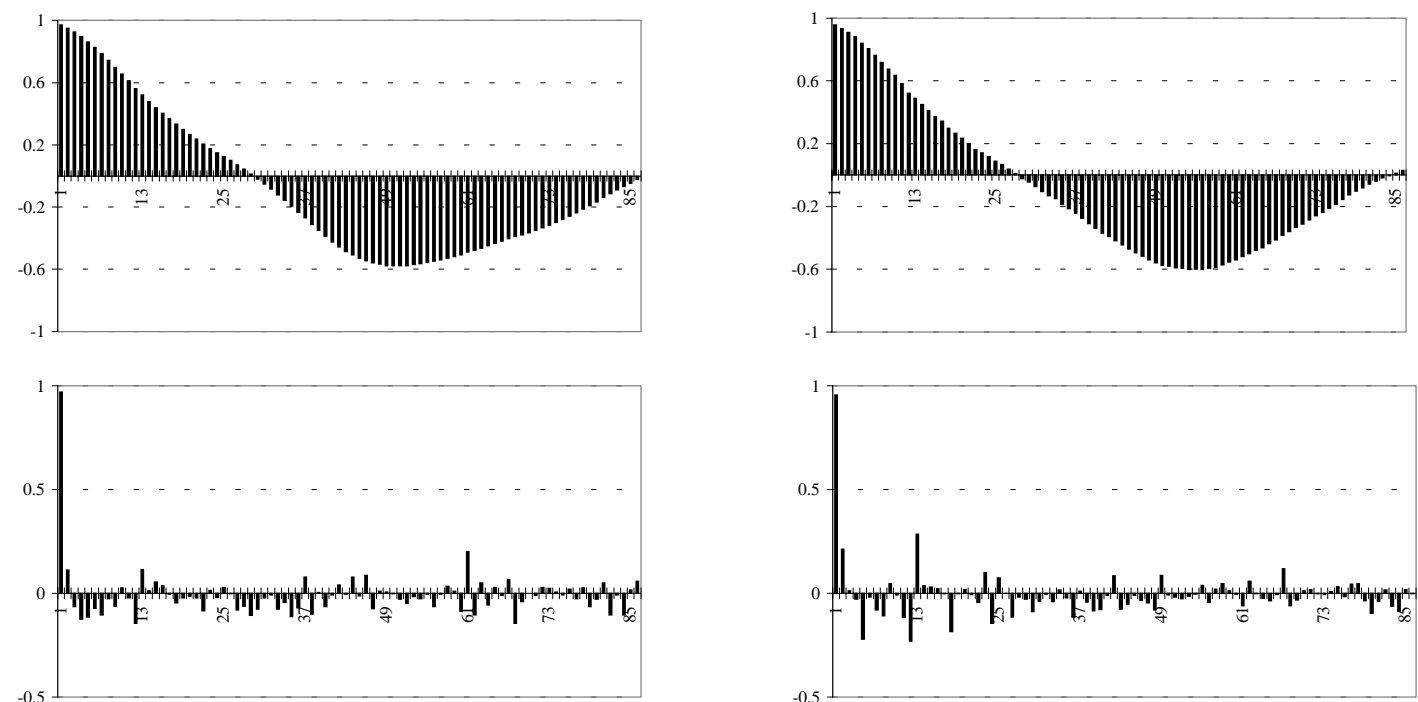

Till sist har autokorrelationen i tidsserierna analyserats och vi nöjer oss här med att redovisa resultat för den relativa reala prisförändringen. Dessa tidsserier uppvisade en hög grad av autokorrelation och för att illustrera detta redovisas grafer över autokorrelation och partiell autokorrelation för den relativa reala prisförändringen för hela riket och Stockholmsregionen i Figur 3. Graferna över autokorrelation uppvisar ett mönster som indikerar s k mean reverting, dvs att en ökning av relativa reala huspriset leder till ytterligare ökningar under ca 2 års tid för att därefter minska. Efter ca 7 år har den negativa korrelationen ebbat ut och korrelation blir ca noll. Mönstret indikerar att tidsserierna kan ha s k långt minne. Ljung-Box testet är signifikant (nollhy- 
potesen om ingen förekomst av autokorrelation förkastas) för de 7 åren för såväl riket totalt som för Stockholmsregionen och för övriga regioner. ${ }^{7}$

Studeras graferna över de partiella autokorrelationerna finner man en "spik" för den första korrelationskoefficienten som nästan är lika med ett. Detta kan föranleda misstanke om en enhetsrot $\mathrm{i}$ tidsserien men våra test $\mathrm{i}$ Tabell 2 indikerar att så inte behöver var fallet. En tumregel som ofta används vid tidsserieanalys är att om en tidsserie uppvisar en "spik" i korreleogrammet för den partiella autokorrelationen, som de två serierna gör i Figur 3, bör en AR-modell kunna användas för att modellera seriens utveckling.

\section{Samband mellan regionernas prisutveckling}

Den statistiska bilden, och nu koncentrerar vi oss på de relativa reala prisförändringar, ger vid handen att vi har ett antal volatila tidsserier där Stockholmsregionen uppvisade högsta graden av volatilitet. Samtliga tidsserier är normalfördelade och verkar vara stationära. Detta gäller även när tidsserierna aggregeras för att omfatta hela riket. Följaktligen kan vi använda dessa tidsserier för olika typer av statistiska och ekonomiska modeller.

Korrelationen mellan den reala prisförändringen mellan de sju regionerna har varit hög under undersökningsperioden. Den lägsta korrelationskoefficienten var 0.72 (mellan industri- och glesbygdskommuner) men en mer normal koefficient mellan regionernas tidsserier landar i intervallet 0,85 till 0,90. Beräknas korskorrelationer emellan regionerna uppvisar dessa också långa "laggar" eller tidseftersläpning på variablerna. Datamaterialet uppvisar således en stor grad av samvariation mellan huspriserna i de olika regionerna vilket också är förväntat och som framgår med all önskad tydlighet av Figur 2. En fråga som är intressant i detta sammanhang är om någon regions prisutveckling påverkar eller dominerar de andra regionernas prisutveckling $\mathrm{i}$ någon större utsträckning. Det ligger närmast till hands att ställa hypotesen att Stockholmsregionen skulle dominera i detta avseende. I engelska undersökningar har man funnit att prisutvecklingen för småhus i Londonområdet har varit en viktig förklaringsfaktor till prisutvecklingen i andra regioner och till prisförändringen i England totalt sett (Muellbauer och Murphy 1997). En fråga som kan ställas är om det finns

\footnotetext{
${ }^{7}$ Ljung-Box testets s k $Q_{\mathrm{LB}}$-statistika testar om summan av autokorrelationskoefficienterna är signifikanta. $Q_{\mathrm{LB}}$-statistikan beräknas som:$$
Q_{L B}=T(T+2) \sum_{j=1}^{p} \frac{r_{j}^{2}}{T-j},
$$

där $T$ är antalet observation och $r_{j}$ är den $j$ :te autokorrelationskoefficienten. Under nollhypotesen är $Q_{\mathrm{LB}} \chi^{2}$-fördelad med lika många frihetsgrader som antalet autokorrelationskoefficienten, $p$.
} 
någon motsvarighet i Sverige till den $\mathrm{s} \mathrm{k}$ South East England effekten på småhuspriserna?

En hög korrelationer föreligger alltså mellan de relativa reala prisförändringarna för regionerna. Detta säger dock inget om att priserna i de olika regionerna påverka varandra. Ett sätt att analysera sambanden mellan regioner är att använda s k kausalitetstest som efter sin upphovsman har fått namnet Granger test. Dessa test har inget med kausalitet i djupare mening att göra utan testar för informationsinnehållet $\mathrm{i}$ en variabel. Vi testar om t ex den relativa reala förändringen i Stockholmsregionens priser kan användas till att "förklara" eller prognostisera en annan regions prisförändring utöver regionens egen och tidigare perioders prisförändringar. Rent formellt kan Grangers (bivariata) test beskrivas med följande ekvation:

$$
y_{t}=C_{0}+\sum_{j=1}^{k} \alpha_{j} y_{t-j}+\sum_{j=1}^{k} \beta_{j} X_{t-j}+\varepsilon_{t}
$$

Låt variabeln $y$ i ekvation (1) stå för den relativa reala prisförändringen i en region och variabeln $x$ för en annan regions. $C_{o}$ och samtliga $\alpha_{j}$ och $\beta_{j}$ är parametrar som skall estimeras. I ett första steg gäller det att skatta ovanstående ekvation, för en given tidseftersläpning $(k)$ för variablerna, och sedan i ett andra steg testa huruvida $\beta_{1}=\beta_{2}=\ldots=\beta_{k}=0$. Om samtliga $\beta$-parametrar ej är signifikant skilda från noll kommer $x$ variabeln inte att påverka $y$ variabeln. Detta är vanligtvis nollhypotesen och brukar uttryckas som att $x$ does not Granger cause $y$. Detta test kan utföras med ett antal olika teststatistika som Wald-test, $F$-test, LM-test och Log likelihood ratio test. Av rent programmeringstekniska skäl har vi valt det sistnämnda testet. Strategin har varit att estimera dels ekvation (1) som den är formulerad ovan utan restriktion, dels med restriktionen att samtliga $\beta$-parametrar är lika med noll. Utifrån differensen mellan skattningarnas log likelihood värde för de två ekvationerna kan ovanstående nollhypotes testas. ${ }^{8}$

Vi har testat för Granger kausalitet emellan prisförändringarna för de olika regionerna med tidseftersläpning ("laggar") på en månad ( $k=1)$, ett kvartal $(k=3)$, ett halvår $(k=6), 9$ månader $(k=9)$ och ett år $(k=12)$. Vid dessa test har vi också experimenterat med att slå ihop regionerna Göteborg och Malmö med medelstora kommuner, benämns 2+3+4 i Tabell 3 där också resultaten redovisas som p-värden (ett p-värde

\footnotetext{
${ }^{8}$ Formellt är $-2 *\left(L_{R}-L_{U}\right), \chi^{2}$-fördelad med lika många frihetsgrader som pålagda restriktioner. $L_{R}$ är log likelihood värdet för ekvationen med restriktioner och följaktligen $\mathrm{L}_{\mathrm{U}} \log$ likelihood värdet för ekvationen utan restriktioner.
} 
mindre än 0.05 indikerar att en variabel är signifikant på åtminstone 5 procents nivån).

Hur skall nu Tabell 3 läsas? Vi väljer att starta högst upp i tabellen för testet med en månads tidseftersläpning och raden för Stockholmsregionen som sedan följes vågrätt. Raden uppvisar enbart nollor (0.00) vilket betyder att nollhypotesen falsifieras och att Stockholmsregionen enligt testet Granger cause var och en av de övriga regionerna. Detta faktum gäller oavsett vilken längd på tidseftersläpningen i variablerna som väljs, upp till 12 månader, vilket framgår om de olika raderna för Stockholm successivt följs ned genom tabellen.

Studeras t ex Göteborgsregionen och med en månads tidseftersläpning erhålls också slutsatsen att denna västkustsmetropol Granger cause var och en av de övriga regionerna inklusive Stockholmsregionen. Ökar vi tidseftersläpningen till ett kvartal respektive ett halvår står sig ovanstående slutsats om Stockholmsregionen exkluderas då p-värdet för denna region uppgick till 0,15 respektive 0,08 . På motsvarande sätt falsifierades inte nollhypotesen beträffande Malmöregionen för Stockholmsregionen vid en månads tidseftersläpning. Således Malmöregionen does not Granger cause Stockholmsregionen, men för övriga regioner falsifierades nollhypotesen. Om tidseftersläpning upp till ett kvartal tillåts håller nollhypotesen inte bara för Stockholmsregionen utan även för Göteborgsregionen. Medelstora kommuner falsifierades nollhypotesen visavi Stockholmsregionen för ett kvartals tidseftersläpning. När Göteborgs- och Malmöregionen samt medelstora kommuner slås samman, $2+3+4$, finner vi att denna variabler var signifikant för Stockholmsregionen endast vid ett kvartals tidseftersläpning ej för övrigt.

Industri- små- och glesbygdskommuner falsifierade inte nollhypotesen visavi Stockholmsregionen med två undantag för olika tidseftersläpning för variablerna. De andra regionerna hade ibland signifikant effekt och ibland inte. Bilden är något splittrad och huvudintrycket av de presenterade Granger testen synes vara att Stockholmsregionen var den region som mest entydigt falsifierade nollhypotesen visavi samtliga övriga regioner. 
Tabell 3 Granger bivariat kausalitetstest på den valda regionuppdelningen för olika tidseftersläpningar på variablerna

\begin{tabular}{|c|c|c|c|c|c|c|c|c|}
\hline & $\begin{array}{l}\text { Stock- } \\
\text { holm }\end{array}$ & $\begin{array}{l}\text { Göte- } \\
\text { borg }\end{array}$ & Malmö & $\begin{array}{c}\text { Medel- } \\
\text { stora }\end{array}$ & $2+3+4$ & Industri & Små & $\begin{array}{l}\text { Gles- } \\
\text { bygd }\end{array}$ \\
\hline \multicolumn{9}{|l|}{1 Månad } \\
\hline 1. Stockholm & & 0,00 & 0,00 & 0,00 & 0,00 & 0,00 & 0,00 & 0,00 \\
\hline 2. Göteborg & 0,00 & & 0,00 & 0,00 & & 0,00 & 0,00 & 0,00 \\
\hline 3. Malmö & 0,51 & 0,01 & & 0,00 & & 0,00 & 0,00 & 0,00 \\
\hline 4. Medelstora & 0,67 & 0,11 & 0,00 & & & 0,00 & 0,12 & 0,00 \\
\hline $2+3+4$ & 0,63 & & & & & 0,00 & 0,00 & 0,00 \\
\hline 5.Industri & 0,95 & 0,18 & 0,00 & 0,00 & 0,01 & & 0,61 & 0,00 \\
\hline 6. Små & 0,54 & 0,02 & 0,00 & 0,00 & 0,00 & 0,00 & & 0,00 \\
\hline 7 .Glesbygd & 0,44 & 0,15 & 0,01 & 0,00 & 0,09 & 0,00 & 0,54 & \\
\hline \multicolumn{9}{|l|}{1 Kvartal } \\
\hline 1. Stockholm & & 0,00 & 0,00 & 0,00 & 0,00 & 0,00 & 0,00 & 0,00 \\
\hline 2. Göteborg & 0,15 & & 0,00 & 0,00 & & 0,00 & 0,00 & 0,00 \\
\hline 3. Malmö & 0,40 & 0,44 & & 0,00 & & 0,00 & 0,00 & 0,00 \\
\hline 4. Medelstora & 0,00 & 0,00 & 0,12 & & & 0,00 & 0,15 & 0,00 \\
\hline $2+3+4$ & 0,08 & & & & & 0,00 & 0,00 & 0,00 \\
\hline 5.Industri & 0,01 & 0,01 & 0,04 & 0,00 & 0,01 & & 0,50 & 0,00 \\
\hline 6. Små & 0,07 & 0,00 & 0,00 & 0,00 & 0,00 & 0,00 & & 0,00 \\
\hline 7 .Glesbygd & 0,38 & 0,26 & 0,10 & 0,00 & 0,79 & 0,00 & 0,55 & \\
\hline \multicolumn{9}{|l|}{1 Halvår } \\
\hline 1. Stockholm & & 0,00 & 0,00 & 0,00 & 0,00 & 0,00 & 0,01 & 0,00 \\
\hline 2. Göteborg & 0,08 & & 0,00 & 0,00 & & 0,00 & 0,00 & 0,00 \\
\hline 3. Malmö & 0,01 & 0,00 & & 0,00 & & 0,00 & 0,00 & 0,00 \\
\hline 4. Medelstora & 0,19 & 0,00 & 0,00 & & & 0,01 & 0,50 & 0,00 \\
\hline $2+3+4$ & 0,85 & & & & & 0,00 & 0,00 & 0,00 \\
\hline 5.Industri & 0,25 & 0,01 & 0,01 & 0,01 & 0,07 & & 0,97 & 0,02 \\
\hline 6. Små & 0,31 & 0,00 & 0,00 & 0,00 & 0,00 & 0,00 & & 0,00 \\
\hline 7 .Glesbygd & 0,57 & 0,26 & 0,14 & 0,00 & 0,28 & 0,00 & 0,33 & \\
\hline \multicolumn{9}{|l|}{9 Månader } \\
\hline 1. Stockholm & & 0,00 & 0,01 & 0,00 & 0,00 & 0,00 & 0,03 & 0,00 \\
\hline 2. Göteborg & 0,01 & & 0,00 & 0,00 & & 0,00 & 0,00 & 0,00 \\
\hline 3. Malmö & 0,01 & 0,00 & & 0,00 & & 0,00 & 0,00 & 0,00 \\
\hline 4. Medelstora & 0,24 & 0,00 & 0,00 & & & 0,03 & 0,27 & 0,00 \\
\hline $2+3+4$ & 0,10 & & & & & 0,00 & 0,00 & 0,00 \\
\hline 5.Industri & 0,33 & 0,04 & 0,13 & 0,01 & 0,09 & & 0,95 & 0,04 \\
\hline 6. Små & 0,59 & 0,00 & 0,01 & 0,00 & 0,02 & 0,00 & & 0,00 \\
\hline 7 .Glesbygd & 0,26 & 0,03 & 0,03 & 0,00 & 0,30 & 0,00 & 0,21 & \\
\hline \multicolumn{9}{|l|}{$1 \AA ̊ r$} \\
\hline 1. Stockholm & & 0,00 & 0,00 & 0,00 & 0,00 & 0,00 & 0,01 & 0,01 \\
\hline 2. Göteborg & 0,00 & & 0,00 & 0,00 & & 0,00 & 0,00 & 0,00 \\
\hline 3. Malmö & 0,03 & 0,00 & & 0,00 & & 0,00 & 0,00 & 0,00 \\
\hline 4. Medelstora & 0,62 & 0,00 & 0,00 & & & 0,02 & 0,03 & 0,00 \\
\hline $2+3+4$ & 0,08 & & & & & 0,00 & 0,00 & 0,00 \\
\hline 5.Industri & 0,40 & 0,11 & 0,01 & 0,05 & 0,19 & & 0,65 & 0,22 \\
\hline 6. Små & 0,01 & 0,00 & 0,00 & 0,00 & 0,00 & 0,00 & & 0,00 \\
\hline 7. Glesbygd & 0,17 & 0,12 & 0,03 & 0,00 & 0,28 & 0,00 & 0,17 & \\
\hline
\end{tabular}

De i tabellen givna värdena är p-värde för log likelihood ratio testen mellan modellen med och utan parameterrestriktion. Ett p-värde som är mindre än 0.05 indikerar att denna variabel har signifikant effekt på den beroende variabeln på minst 5 procents nivån. För utförligare förklaring se text. 
Informationsinnehållet i de relativa reala priserna för småhus på andrahandsmarknaden för kan således vara till användning när den relativa prisutvecklingen i de andra regionerna skall "förklaras" eller prognostiseras. Den slutsats som vi är beredda att dra från de bivariata Granger testen är att Stockholmsregionen verkar ha samma effekt på prisutvecklingen för andrahandsmarknaden för småhus i övriga Sverige som Londonregionen har för övriga England.

\section{Huspriser och makrovariabler}

Stockholmsregionen verkar således ligga före beträffande prisutvecklingen jämfört med övriga regioner och testen i föregående avsnitt indikerar att prisimpulser från Stockholmsområdet kan sägas sprida sig över landet. Skälen till att det är så kan vara flera men viktigt är antagligen att konjunkturuppgångar och -nedgångar sannolikt först manifesteras i Stockholmsområdet. I detta avsnitt, där informationsinnehållet i ett antal makrovariabler analyseras visavi prisutvecklingen för småhus, har vi valt göra detta enbart för Stockholmsregionen och aggregerat för Sverige totalt. Skälet till denna strategi är att Stockholmsregionen verka "leda" beträffande den reala utvecklingen av småhuspriser och att studera huruvida ett antal makrovariabler påverkar andrahandsmarknaden för regionens småhuspriser kan ge en indikation om statistiskt sett viktiga bestämningsfaktorer. Samma analys görs för den relativa reala prisutvecklingen för hela Sverige men inte för övriga regioner.

De statistiska testerna i detta avsnitt görs också med Granger test men nu inte enbart med bivariata test utan även mulivariata test. Den första typen av test, bivariata, är likvärdiga med de tidigare diskuterade testen i enlighet med ekvation (1) men med den skillnaden att $x$ variabeln nu utgörs av en makrovariabel. De multivariata testen bygger på att ett flertal oberoende variabler, med given tidseftersläpning, inkorporeras i ekvation (1) varefter de skattade parmetrarna variabel för variabel testas huruvida dessa är signifikant skilda från noll eller inte. 
Tabell 4 Granger (bivariata) kausalitetstest för relativa reala småhuspriser för Stockholmsregionen (övre delen av tabellen) och landet totalt med tidseftersläpning från en månad till ett år för ett antal finansiella och reala makrovariablerna. Redovisad statistika är p-värden.

\begin{tabular}{|c|c|c|c|c|c|c|c|c|c|c|c|c|c|}
\hline & \multicolumn{3}{|c|}{ Relativ 12 mån. förändring } & \multicolumn{3}{|c|}{12 mån. förändring } & \multirow{2}{*}{$\begin{array}{l}\text { Termins- } \\
\text { premie }\end{array}$} & \multirow[b]{2}{*}{ Real M0 } & \multirow[b]{2}{*}{ Real M3 } & \multicolumn{2}{|c|}{ Relativ 12 mån. förändring } & \multirow[b]{2}{*}{$\begin{array}{c}\text { Försäljning, } \\
\text { småhus } \\
\text { Stockholm }\end{array}$} & \multirow[b]{2}{*}{$\begin{array}{l}\text { Försäljning, } \\
\text { småhus totalt }\end{array}$} \\
\hline & $\begin{array}{l}\text { Nya order, } \\
\text { industrin }\end{array}$ & $\begin{array}{l}\text { Industripro- } \\
\text { duktion }\end{array}$ & $\begin{array}{l}\text { Nybilsregi- } \\
\text { strering }\end{array}$ & Arbetslöshet & $\begin{array}{l}\text { Real kort- } \\
\text { ränta efter } \\
\quad \text { skatt }\end{array}$ & $\begin{array}{l}\text { Real lång- } \\
\text { ränta efter } \\
\text { skatt }\end{array}$ & & & & Realt AFGX & $\begin{array}{c}\text { Realpris } \\
\text { bostadskost- } \\
\text { nad }\end{array}$ & & \\
\hline 1 & 0.233 & 0.558 & 0.001 & 0.435 & 0.001 & 0.004 & 0.010 & 0.010 & 0.012 & 0.050 & 0.017 & 0.256 & 0.043 \\
\hline 2 & 0.024 & 0.270 & 0.000 & 0.350 & 0.000 & 0.000 & 0.017 & 0.004 & 0.004 & 0.002 & 0.008 & 0.007 & 0.000 \\
\hline 3 & 0.041 & 0.061 & 0.000 & 0.425 & 0.000 & 0.000 & 0.020 & 0.001 & 0.004 & 0.003 & 0.009 & 0.003 & 0.000 \\
\hline 4 & 0.067 & 0.104 & 0.000 & 0.059 & 0.000 & 0.000 & 0.045 & 0.002 & 0.003 & 0.002 & 0.021 & 0.004 & 0.000 \\
\hline 5 & 0.146 & 0.158 & 0.000 & 0.329 & 0.000 & 0.000 & 0.222 & 0.008 & 0.036 & 0.056 & 0.164 & 0.049 & 0.001 \\
\hline 6 & 0.317 & 0.018 & 0.001 & 0.562 & 0.000 & 0.001 & 0.269 & 0.024 & 0.072 & 0.034 & 0.214 & 0.022 & 0.002 \\
\hline 7 & 0.526 & 0.031 & 0.002 & 0.870 & 0.000 & 0.001 & 0.422 & 0.004 & 0.190 & 0.003 & 0.327 & 0.030 & 0.012 \\
\hline 8 & 0.722 & 0.047 & 0.003 & 0.706 & 0.000 & 0.002 & 0.585 & 0.002 & 0.051 & 0.003 & 0.426 & 0.022 & 0.010 \\
\hline 9 & 0.817 & 0.008 & 0.004 & 0.780 & 0.000 & 0.003 & 0.614 & 0.001 & 0.084 & 0.005 & 0.276 & 0.013 & 0.011 \\
\hline 10 & 0.877 & 0.011 & 0.002 & 0.226 & 0.000 & 0.001 & 0.627 & 0.001 & 0.102 & 0.007 & 0.340 & 0.019 & 0.014 \\
\hline 11 & 0.783 & 0.016 & 0.003 & 0.119 & 0.000 & 0.000 & 0.767 & 0.001 & 0.065 & 0.011 & 0.484 & 0.016 & 0.009 \\
\hline 12 & 0.893 & 0.008 & 0.001 & 0.034 & 0.000 & 0.000 & 0.916 & 0.002 & 0.017 & 0.032 & 0.823 & 0.002 & 0.000 \\
\hline 1 & 0.009 & 0.048 & 0.004 & 0.482 & 0.000 & 0.000 & 0.003 & 0.004 & 0.004 & 0.007 & 0.002 & 0.093 & 0.001 \\
\hline 2 & 0.008 & 0.064 & 0.003 & 0.369 & 0.000 & 0.000 & 0.006 & 0.000 & 0.002 & 0.002 & 0.001 & 0.002 & 0.000 \\
\hline 3 & 0.023 & 0.015 & 0.014 & 0.524 & 0.000 & 0.000 & 0.004 & 0.000 & 0.006 & 0.005 & 0.002 & 0.000 & 0.000 \\
\hline 4 & 0.084 & 0.077 & 0.058 & 0.746 & 0.000 & 0.000 & 0.022 & 0.000 & 0.008 & 0.035 & 0.023 & 0.001 & 0.000 \\
\hline 5 & 0.292 & 0.139 & 0.366 & 0.934 & 0.000 & 0.000 & 0.092 & 0.000 & 0.019 & 0.075 & 0.121 & 0.008 & 0.000 \\
\hline 6 & 0.417 & 0.046 & 0.588 & 0.834 & 0.000 & 0.000 & 0.115 & 0.000 & 0.022 & 0.155 & 0.203 & 0.005 & 0.000 \\
\hline 7 & 0.596 & 0.050 & 0.474 & 0.533 & 0.001 & 0.000 & 0.232 & 0.000 & 0.066 & 0.005 & 0.252 & 0.009 & 0.000 \\
\hline 8 & 0.721 & 0.036 & 0.361 & 0.517 & 0.001 & 0.000 & 0.268 & 0.000 & 0.112 & 0.003 & 0.358 & 0.009 & 0.001 \\
\hline 9 & 0.759 & 0.040 & 0.198 & 0.413 & 0.000 & 0.000 & 0.342 & 0.001 & 0.102 & 0.003 & 0.465 & 0.000 & 0.000 \\
\hline 10 & 0.697 & 0.036 & 0.142 & 0.154 & 0.000 & 0.000 & 0.432 & 0.000 & 0.138 & 0.004 & 0.229 & 0.000 & 0.000 \\
\hline 11 & 0.225 & 0.019 & 0.073 & 0.161 & 0.001 & 0.000 & 0.368 & 0.000 & 0.202 & 0.006 & 0.209 & 0.000 & 0.000 \\
\hline 12 & 0.249 & 0.015 & 0.125 & 0.048 & 0.000 & 0.000 & 0.510 & 0.000 & 0.154 & 0.008 & 0.486 & 0.000 & 0.000 \\
\hline
\end{tabular}


De finansiella och reala makrovariablerna som använts i analysen framgår av Tabell 4. Det skall påpekas igen att månadsdata används och många av de reala makrovariabler som skulle vara önskvärda att använda bara finns tillgängliga på kvartalsfrekvens. Uppgifter över t ex hushållens disponibla inkomst, konsumtion och förmögenhet finns inte månadsvis men väl på kvartalsnivå. Däremot finns vissa data för undersökningarna över hushållens framtidsförväntningar, de s k HIPundersökningarna, tillgängliga på månadsbasis men dock först fr o m 1993. För tidigare perioder enbart på kvartalsbasis. ${ }^{9}$ Aggregerade finansiella variabler som räntor och likviditetsvariabler är tillgängliga på månadsbasis vilket också gäller för tillgångspriserna för aktier och konsumentpriserna. Detta gäller också för några reala variabler som t ex arbetslöshet och industriproduktionsindex.

I brist på data för vissa reala variabler har ett antal "proxy"-variabler använts. Tidsserierna över industrins nya order, industriproduktionsindex, nyregistrering av personbilar samt arbetslösheten är alla variabler som speglar den realekonomiska utvecklingen och som därmed bör kunna användas som "proxys" för inkomst- och efterfrågeutvecklingen hos hushållen.

De räntor som används i analysen är 3 månadsräntan på statsskuldsväxlar och 5-års räntan på statens obligationslån. Terminspremien definieras som differensen mellan långa och korta räntan och som likviditetsvariabler har använts dels den snäva definitionen på penningmängden $\mathrm{M} 0$, dels den mer vida definitionen M3. ${ }^{10}$ För att spegla utvecklingen av aktiepriserna utnyttjas Affärsvärldens Generalindex och som realpris för bostadskostnaden har använts såväl prisutvecklingen för bostadskomponenten enligt KPI samt produktionskostnadsindex för nybyggnation. Slutligen har omsättningen av småhus för Stockholmsregionen och riket totalt använts som oberoende variabel.

\section{Bivarat test}

Resultaten av de bivariata Granger testen för makrovariabler och huspriser återges $\mathrm{i}$ Tabell 4. Ett resultat som förtjänar att kommenteras först är att ränteförändringen does Granger cause relativa reala prisförändringar i småhusfastigheter för Stock-

\footnotetext{
${ }^{9} \mathrm{Nu}$ behöver inte just brist på månadsdata från HIP-undersökningarna vara ett problem i sig då en tidigare empirisk analys pekat på att utvecklingen av räntan är en viktig förklaringsfaktor bakom hushållen framtidsbedömningar, se Berg och Bergström (1996). Korta och långa räntor ingår i vår analys vilket kan innebära att en del av den latenta variabeln "framtidsförväntningar" från HIP-undersökningarna fångas upp.

${ }^{10}$ M0 definieras som allmänhetens innehav av sedlar och mynt och M3 som M0 plus allmänhetens inlåning i banker och innehav av bankcertifikat.
} 
holmsregionen och riket totalt oavsett tidseftersläpningsperioden, åtminstone upp till 12 månader. Detta resultat är i samklang med grundläggande prissättningsteori för fastigheter; priset eller nuvärdet på en fastighet utgörs av det diskonterade värdet av framtida kassaflöde som fastigheten genererar. En ränteförändring skall således teoretiskt sett påverka priset vilket våra resultat indikerar.

Däremot falsifierade terminspremien nollhypotesen endast för en tidseftersläpning upp till 4 månader, ej mer. I makroanalyser används differensen mellan lång och kort ränta som en förväntningsvariabel om den allmänna ekonomiska utvecklingen. Argumentet är följande; om marknaden tror på en konjunkturuppgång innebär det att efterfrågan kommer att öka vilket sätt en press uppåt på priserna i ekonomin och därmed den långa räntan. En positiv marginal mellan lång och kort ränta indikerar således en förväntad konjunkturuppgång och en negativ marginal en konjunkturnedgång. Denna tolkning är kanske den rimliga i detta sammanhang. Terminspremien ser vi således som en förväntningsvariabel för den ekonomiska utvecklingen.

Variablerna M0 och omsättningen av småhus totalt för riket falsifierar nollhypotesen oavsett tidseftersläpningensperioden för såväl Stockholmsregionen som hela riket. Den mer vitt definierade likviditetsvariabeln M3 falsifierar inte nollhypotesen på samma entydiga sätt som M0. Utvecklingen av aktiepriserna verkar entydigt att ha informationsinnehåll beträffande småhusprisutvecklingen i Stockholmsregionen men inte för landet som helhet. För realpris på bostadskostnader falsifieras nollhypotesen när tidseftersläpningen uppgår till högst 4 månader.

Ser vi till de första fyra variablerna i tabellen som är av mera real karaktär är resultatet av testen skiftande. Förändringen i arbetslösheten falsifierar, med ett undantag, aldrig nollhypotesen. Nybilsregistreringen tenderar att ha en annan effekt än vad nollhypotesen implicerar för Stockholmsregionen medan bilden inte är lika entydig för prisförändringarna för hela riket. För att förändringar i industriproduktionen skall falsifiera nollhypotesen krävs tidseftersläppningar i variablerna som uppgår till minst 6 månader. Variabeln orderingången till industrin verkar inte ha någon effekt.

\section{Multivariat test}

Vid modelleringen av Granger testen när ett flertal oberoende variabler har inkorporerats har vi experimenterat med de olika makrovariablerna som tidigare använts i de bivariata testen. Att inkludera alla dessa som högerledsvariabler i en och samma modell kommer sannolikt att resultera i att ett flertal av dessa variabler inte kommer vara signifikanta till följd av bl a den multikolinearitet som föreligger emellan dessa makrovariabler. Strategin har istället varit att använda ett begränsat antal av dessa 
makrovariabler som utifrån ekonomiska skäl kan anses fånga t ex inkomstförväntningar och andra faktorer som påverka småhuspriserna på andrahandsmarknaden. Därvid har vi efter ett visst experimenterande stannat vid den variabeluppsättning som finns presenterad i Tabell 5. ${ }^{11}$ Precis som de bivariata testen nöjer vi oss med att analysera den relativa reala prisutvecklingen för Stockholmsregionen och hela riket.

Industriproduktion, nybilsregistrering och arbetslöshet är variabler från ekonomins reala sfär som bör vara av betydelse för hushållens inkomstutveckling och förväntningarna om densamma. Som redan nämnts i samband med de bivariata testen förväntas att priset på en fastighet förändras med räntan; realränta efter skatt används för att testa för denna effekt. Som likviditetsvariabeln har M0 använts (M3-variabeln blev aldrig signifikant) och denna variabel tillsammans med räntevariabeln var de finansiella variabler som användes. Terminspremie och aktieindex, som i sig kan ses som finansiella variabler, betraktas i detta sammanhang som förväntningsvariabler beträffande den ekonomiska utvecklingen. Aktiepriserna bör spegla marknadens bedömning om den framtida ekonomiska utvecklingen. ${ }^{12}$

Resultaten av de multivariata testen indikerar att likviditetsvariabeln, M0, aldrig förkastade nollhypotesen medan aktieindex förkastade denna hypotes när tidseftersläpningen översteg en månad för båda prisserierna. För den korta realräntan efter skatt gäller det omvända mot aktieindexet; nollhypotesen förkastas enbart vid en periods eftersläpning. För arbetslöshetsvariabeln gäller samma sak som för korta räntan för Stockholmsregionen. För hela riket däremot förkastas nollhypotesen endast vid 12 månaders eftersläpning. Industriproduktionen och nybilsregistreringen förkastar också nollhypotesen vid den längsta tidseftersläpningen för båda prisvariablerna. Den enda variabel som i det multivariata testet förkastade nollhypotesen för båda prisserierna och för alla perioder med olika tidseftersläpningar var terminspremien.

I de gjorda testen framkommer således att informationsinnehållet i såväl terminspremien som aktieindex synes vara viktiga för utvecklingen av huspriserna i såväl

\footnotetext{
11 Till hjälp för modellval av det multivariata testet har vi haft de bivariata test mellan utveckling av huspriser och makrovariabler som återges i appendix, Tabell A1. Till skillnad mot de bivariata test mellan huspris å ena sidan och makrovariablerna å andra sidan som återges i Tabell 4 har bivariata Granger test mellan var och en av samtliga variabler som ingår i Tabell 4 gjorts för tidseftersläpningar på 1, 3, 6, 9 och 12 månader. Testen i appendix berör dock endast prisutvecklingen i Stockholmsregionen och makrovariablerna.

12 Att den relativa reala utvecklingen av aktieindex syns vara en viktig "förklaringsvariabel" framgår av appendix. Tabell Al i detta appendix redovisas bivariata Granger test för Stockholmsregionens och de $i$ Tabell 4 använda makrovariablerna. Alla 13 variablerna testas mot varandra med tidseftersläpningar på 1, 3, 6, 9 och 12 månader. Den variabel som falsifierade flest nollhypoteser för de andra variablerna, oavsett tidseftersläpning, var den relativa reala utvecklingen av aktieindex. Däremot var det bara i några enstaka fall, oavsett tidseftersläpning, som nollhypotesen att andra variabler does not Granger cause aktieindex falsifierades.
} 
Stockholmsregionen som för hela landet. Att så skall vara fallet förefaller vara rimligt utifrån en rent teoretisk utgångspunkt då vi ser dessa två variabler som viktiga när hushållen formar sina förväntningar om framtiden. Industriproduktionens och nybilsregistreringens informationsinnehåll visavi prisvariablerna uppenbaras först vid den längsta tidseftersläpningen i variablerna. Notera att detsamma gäller för arbetslöshetsvariabeln för hela riket medan för Stockholmsregionen och arbetslösheten förkastas nollhypotesen endast när tidseftersläpningen var en månad.

Tabell 5 Granger (multivariat) kausalitetstest med relativa real prisutveckling för småhus för Stockholmsregionen och hela riket (beroende variabel) och ett antal makrovariabler med längd på variablernas tidseftersläpning från 1, 3, 6, 9 och 12 månader. Redovisad statistika är p-värden

\begin{tabular}{lccccc}
\hline Stockholm & 1 & 3 & 6 & 9 & 12 \\
Industriproduktion & 0.89 & 0.87 & 0.94 & 0.49 & 0.05 \\
Nybilsregistrering & 0.08 & 0.89 & 0.95 & 0.04 & 0.00 \\
Arbetslöshet & 0.04 & 0.29 & 0.92 & 0.82 & 0.10 \\
Kort realränta efter skatt & 0.01 & 0.06 & 0.41 & 0.99 & 0.99 \\
Terminspremie & 0.00 & 0.00 & 0.00 & 0.00 & 0.00 \\
Realt M0 & 0.51 & 0.78 & 1.00 & 1.00 & 0.88 \\
Realt AFGX & 0.13 & 0.01 & 0.00 & 0.00 & 0.00 \\
Totalt & & & & & \\
Industriproduktion & 0.63 & 1.00 & 0.96 & 0.43 & 0.01 \\
Nybilsregistrering & 0.75 & 0.87 & 0.73 & 0.08 & 0.00 \\
Arbetslöshet & 0.43 & 0.89 & 0.98 & 0.06 & 0.00 \\
Kort realränta efter skatt & 0.01 & 0.11 & 0.53 & 0.99 & 0.78 \\
Terminspremie & 0.00 & 0.00 & 0.00 & 0.00 & 0.00 \\
Realt M0 & 0.44 & 0.11 & 0.14 & 0.74 & 0.74 \\
Realt AFGX & 0.13 & 0.01 & 0.00 & 0.00 & 0.00 \\
\hline De tvă forsta och tvă
\end{tabular}

De två första och två sista variablerna är uttryckta som relativa 12 månaders förändringar. Arbetslöshet och kort realränta efter skatt är uttryckta som 12 månaders differenser. Terminspremien beräknas som differensen mellan 5-åriga SSX och 3 månads statsskuldsväxel.

\section{Vektorautoregressiv model}

Att olika reala och finansiella variabler är viktiga förklaringsfaktorer till utvecklingen av priserna på andrahandsmarknaden för småhus har tidigare studier visat och våra resultat ovan styrker detta. ${ }^{13}$ I detta avsnitt skall vi försöka att fördjupa analysen genom att använda en modell som simultant tar hänsyn till förändringen i de relativa reala huspriserna för Stockholmsregionen, relativa förändringen i nyregistreringen av bilar samt förändringen i arbetslösheten. I denna modell ingår också ett antal exogena variabler som vi återkommer till.

Grunden för modellen ligger den ekonomiska teorin och intuitionen(!) att hushållen planerar konsumtion utifrån bl a förmögenheten, förväntad framtida realräntor och

13 Se Englund m fl (1995) och Hort (1997). 
inkomster (livscykelteorin). Utvecklingen av huspriser, konsumtion och arbetslöshet är endogena och påverkar varandra. Således kommer utvecklingen av huspriser att ha betydelse för hushållens förmögenhetsutveckling samt för konsumtion och sysselsättning. Konsumtionsutvecklingen bör påverka sysselsättning och kanske mera indirekt huspriser medan arbetslösheten direkt förväntas ha effekt på huspriser och konsumtion. Dessa samband kan också uttryckas som att utvecklingen av huspriser och arbetslöshet kan ses som "proxys" för hushållens förväntningar beträffande inkomstoch förmögenhetsutvecklingen och därmed indirekt påverkar konsumtionsutvecklingen.

De variabler som krävs för att genomföra analysen är således utvecklingen av huspriser, konsumtion och arbetslöshet. Vi analyserar enbart Stockholmsregionen vilket innebär att det vore önskvärt att ha regionala tidsserier för denna region vilket vi endast har för småhuspriserna. Vi arbetar med månadsdata. Hushållens konsumtion finns endast på kvartalsbasis ej på månadsbasis och ej heller regionalt för Stockholmsregionen. Nyregistrering av personbilar, för hela riket, har därför valts som en "proxy" för privat konsumtion. Den valda konsumtionsproxyn" är starkt korrelerad med utvecklingen av konsumtionen för hela riket med olika indelningar på kvartalsfrekvens. ${ }^{14}$

De i modellen ingående exogena variablerna har valts utifrån teoretiska övervägande och ett visst mått av experimenterande. Som exogena variabler har valts kort realränta efter skatt, terminspremie, relativ real förändring i aktieindex samt relativ förändring i nya order till industrin. De exogena variablerna har specificerats med en viss variation i tidseftersläpningen - se appendix Tabell A2 där resultaten för den skattade modellen återges. Tidseftersläpningen för de tre endogena variablerna uppgår till 5 månader.

Den använda modellen brukar benämnas vektor autoregressiv, VAR-modell. I matematisk form kan VAR-modellen skrivas som ekvation (2), där $\mathbf{y}$ respektive $\mathbf{x}$ representerar en vektorer av endogena respektive exogena variabler. A och B är koefficientmatriser som skall estimeras samt $\mathbf{e}$ en vektor för slumpfel eller s k innovationer. ${ }^{15}$ Dessa innovationer är naturligtvis okorrelerade med respektive högerledsvariabler i sin ekvation men sannolikt korrelerade sinsemellan ekvationerna.

\footnotetext{
14 Korrelationskoefficienterna mellan relativ förändring av nyregistrering av personbilar och relativa förändringen av total konsumtionsvolym, varaktiga och icke-varaktiga konsumtionsvaror uppgick till 0.82, 0.98 respektive 0.85 för kvartalsdata 1981:1 - 97:2.

$15 \mathrm{Vi}$ arbetar med en VAR-modell utan restriktioner på de skattade parametrarna. Vi antar också att det finns exogena variabler i modellen vilket medför att Johansens kointegrationstest inte är lämpligt Johansens test utgår ifrån att det i VAR-modellen endast finns endogena variabler och test görs för att utröna om det finns några kointegrerade vektorer.
} 
$\mathbf{y}_{t}=\mathbf{A}_{1} \mathbf{y}_{t-1}+\ldots+\mathbf{A}_{\mathrm{N}} \mathbf{y}_{t-\mathrm{N}}+\mathbf{B}_{1} \mathbf{x}_{t-1}+\ldots+\mathbf{B}_{\mathrm{N}} \mathbf{x}_{t-\mathrm{N}}+\mathbf{e}_{t}$

I vårt fall består systemet av tre ekvationer. De endogena variablerna i y-vektorn utgörs av utvecklingen av reala huspriserna i Stockhomsregionen, nybilsregistreringen samt förändringen i arbetslösheten. I x-vektorn ingår utöver en konstant de ovan nämnda fyra exogena variablerna. Ekvationssystemet har estimerats för perioden 1982:6 - 1997:07 och skattningsresultaten återges i appendix.

Tekniken med VAR-modeller brukar ofta användas i samband med prognosarbete och denna metodik är speciellt lämplig när systemet enbart består av endogena variabler. Vårt syfte är emellertid inte att prognostisera de tre endogena variabler vi arbetar med utan att studera samvariationen mellan dessa och stabiliteten i systemet. För detta syfte brukar man vanligtvis använda s k impuls-responsfunktioner i VARsystemet. Vi studerar effekten av en störning, innovation, i respektive endogena variabel och hur denna innovation i sin tur påverka de andra endogena variablerna. Utvecklingen av huspriser, nybilsregistrering och arbetslösheten har således varsin innovation, $\varepsilon^{1}, \varepsilon^{2}$, respektive $\varepsilon^{3}$. Om dessa tre innovationer är okorrelerade varandra blir tolkningen av impuls-responsfunktionerna enkel och okomplicerad. Dessa endogena variabler med tidseftersläpningarna från 1 till 5 månader ingår i varje ekvation tillsammans med de exogena variablerna och innovationen. När systemet estimeras skattas samtliga $\alpha$-parametrar samt de parametrar som multipliceras med de exogena variablerna.

$$
\begin{aligned}
& y_{t}^{1}=\sum_{i=1}^{5} \alpha_{i}^{1,1} y_{t-i}^{1}+\sum_{i=1}^{5} \alpha_{i}^{1,2} y_{t-i}^{2}+\sum_{i=1}^{5} \alpha_{i}^{1,3} y_{t-i}^{3}+\text { Exogenavar }+\varepsilon_{t}^{1} \\
& y_{t}^{2}=\sum_{i=1}^{5} \alpha_{i}^{2,1} y_{t-i}^{1}+\sum_{i=1}^{5} \alpha_{i}^{2,2} y_{t-i}^{2}+\sum_{i=1}^{5} \alpha_{i}^{2,3} y_{t-i}^{3}+\text { Exogenavar }+\varepsilon_{t}^{2} \\
& y_{t}^{3}=\sum_{i=1}^{5} \alpha_{i}^{3,1} y_{t-i}^{1}+\sum_{i=1}^{5} \alpha_{i}^{3,2} y_{t-i}^{2}+\sum_{i=1}^{5} \alpha_{i}^{3,3} y_{t-i}^{3}+\text { Exogena var }+\varepsilon_{t}^{3}
\end{aligned}
$$

Om systemet "chockas" med en innovation som motsvarar en standardavvikelse av den endogena variabeln ifråga, används impuls-responsfunktionen till att studera effekten av denna chock på samtliga tre endogena variabler. Om vi t ex väljer $\varepsilon^{1}$ så är denna således innovationen för utvecklingen av huspriserna. Impuls-responsfunktionen för $\varepsilon^{1}$ följer utvecklingen av effekten på det tre endogena variablerna av en standardavvikelses chock i de relativa reala huspriserna för Stockholmsregionen. I första perioden kommer enbart utvecklingen av huspriserna att påverkas då de endogena variablerna ingår med tidseftersläpning i ekvationssystemet. I nästa period 
kommer samtliga tre ekvationer att påverkas i och med att utvecklingen av huspriserna med en periods tidseftersläpning ingår i samtliga ekvationer, under förutsättning att den skattade husprisparametern är skild från noll. I andra perioden kan samtliga predeterminerade endogena variabler påverka de tre endogena variablerna och så vidare. $\mathrm{M} \mathrm{h}$ a impuls-responsfunktionen kan man studera utvecklingen av systemet; vilka variabler påverkas av respektive chock, går det mot en ny jämvikt och i så fall hur lång tid tar det. Denna procedur upprepas för varje endogen variabel. ${ }^{16}$ Resultaten från experiment med modellen återges i Figur 4.

Impuls-respons övningarna ger vid handen att chocker från den använda "konsumtionsproxyn" inte påverkar utvecklingen av huspriser och arbetslöshet - se högra grafen första raden i Figur 4. Däremot har en chock i förändringen i relativa reala huspriser en klar effekt på "konsumtionsproxyn" men ingen effekt på förändringen i arbetslösheten - vänstra grafen första raden. En chock i förändringen i arbetslösheten däremot minskar såväl relativa reala förändringen i huspriser som relativa förändringen i nybilsregistreringen - nedersta grafen.

\footnotetext{
16 Som nämnts tidigare blir tolkningen av impuls-responsfunktionerna enkel och okomplicerad om innovationer är okorrelerade varandra. Är dessa däremot inte oberoende av varandra betyder det att dessa har en gemensam komponent som inte kan bli identifierad. Ett godtyckligt sätt att komma runt detta problem är att utgå ifrån att denna gemensamma effekt i feltermerna helt finns i den innovation som först chockar VAR-systemet. I tekniska termer beskrivs detta som att feltermerna ortogonaliserats genom en s k Choleskei dekomponering vilket innebär att kovariansmatrisen för residualerna blir diagonal. En följd av detta antagandet är ordningen av de endogena variablerna i ekvationssystemet kan förändra utvecklingen av impuls-responsfunktionerna. Ett sätt att studera om detta antagande har en förödande effekt på impuls-responsfunktionerna är naturligtvis att ändra ordningen av de endogena variablerna. Tilläggas kan att $\mathrm{i}$ våra test har vi ändrat ordningen mellan variablerna på de möjliga sätt som finns utan att resultaten från de som redovisas i Figur 4 har förändrats.
} 
Figur 4 Respons-impuls grafer över en standardavvikelses innovation $i$ var och en av de tre endogena variablerna $i$ VAR modellen

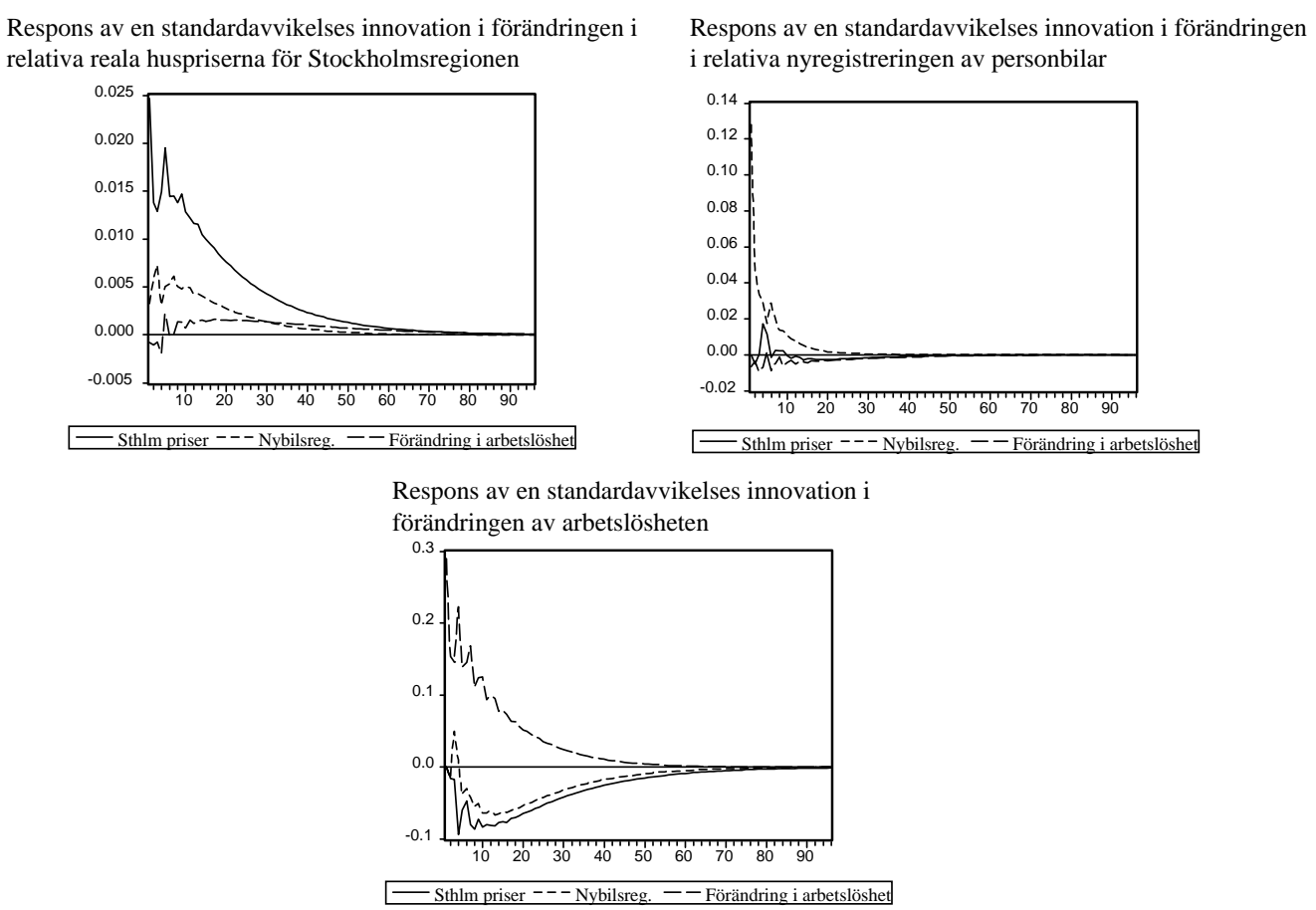

Den använda "konsumtionsproxyn" verkar inte ha något informationsinnehåll för de två övriga endogena variablerna eftersom en chock i denna variabel inte påverkar de övriga. En chock i den relativa reala förändringen i huspriser har en positiv effekt på "konsumtionsproxyn" vilket kan tolkas som en förmögenhetseffekt; en real ökning i huspriser ökar hushållens förmögenhet vilket i sin tur påverka konsumtionen. I vår tidigare diskussion har förändringen i arbetslösheten setts som en proxyvariabel för hushållens inkomstförväntningar. Om denna tolkning är rimlig har en negativ chock i förväntningarna om framtida inkomster (ökad arbetslöshet) kraftiga effekter på såväl huspriser som konsumtion. Noteras kan också att effekten av chocken blir tillfällig men anpassningen mot jämvikt blir en långt utdragen process att uppnå det nya jämviktsläget tar det 4-5 år. Sannolikt sammanhänger detta med husprisernas starka egenprisdynamik.

\section{Sammanfattning}

I uppsatsen analyseras utvecklingen av småhuspriserna på andrahandsmarknaden.

Datasetet består av månadsdata från januari 1981 till juli 1997 och har delats upp i tre storstadsregioner och fyra s k LA-regioner. Test indikerar att logaritmen för de reala huspriserna för regionerna och riket totalt var I(1) och säsongsdifferensen var i de 
flesta fall I(0). Relativa reala prisutvecklingen för samtliga regioner uppvisar stark egenprisdynamik och korreleogrammen för autokorrelationen för dessa variabler överensstämmer med ett mönster som är förenligt med mean reverting och långt minne. Grangers bivariata test indikerar att relativa reala prisutvecklingen för Stockholmsregionen har informationsinnehåll för alla de övrig regionerna med en tidseftersläpning på upp till ett år. Stockholmsregionen förefaller entydigt "leda" prisutvecklingen på småhusmarknaden, en effekt som överensstämmer med den effekt Londonregionen har på den brittiska småhusmarknaden.

Bivariata och multivariata Granger test mellan reala prisutvecklingen i Stockholmsregionen och ett antal reala och finansiella makrovariabler visar att dess variabler hade informationsinnehåll eller "förklaringsvärde". Därvid var realränta efter skatt, terminspremien, utvecklingen på aktiemarknaden, industriproduktionen samt en "proxy-variabel" för konsumtionsutvecklingen viktiga faktorer. En enkel VARmodell med real prisutveckling i Stockholmsregionen, "konsumtionsproxyn" och förändring $\mathrm{i}$ arbetslöshet som endogen variabler och ett antal exogena variabler har estimerats. Experiment med impuls-responsfunktioner indikerar bl a att en chock i arbetslösheten ger en kraftig påverkar i utvecklingen av huspriser och konsumtionen och att anpassningen mot en ny jämvikt tar 4-5 år.

\section{Referenser}

Bayoumi T (1993), "Financial deregulation and household saving", The Economic Journal, 103, 1432-43.

Berg L and J Lyhagen (1998), "The dynamics in Swedish house prices - an emperical time series analysis", Workíng Paper no. 12, IBF, Uppsala Universitet..

Berg L and R Bergström (1995), "Consumption, income, wealth and household debt An econometric analysis of the Swedish experience 1970-1992", Scandinavian Journal of Economics, 97, 421-39..

Berg L (1994), "Household savings and debts: the experience of the Nordic countries", Oxford Review of Economic Policy, 10, 42-53.

Brodin P A and R Nymoen (1992), "Wealth effects and exogeneity: the Norwegian consumption function 1966(1) - 1989(4)", Oxford Bulletin of Economics and Statistics, 54, 431-59.

Campell J, A W Lo and A C MacKinley (1997), Financial Econometrics, Princeton University Press, Princeton New Jersey.

Cho M (1996), "House price dynamics: A survey of theoretical and emperical issues", Journal of Housing Research, 7, 145-72.

Ekman E (1997), Household and Corporate Behaviour under Uncertainty, Economic Studies 29, Department of Economics. Uppsala University.

Englund P and Y M Ioannides (1997), "House price dynamics: An international empirical perspective", Journal of Housing Economics, 6, 119-36.

Englund P, P H Hendershott and B Turner (1995), "The tax reform and the housing market", Swedish Economic Policy Review, 2, 319-56. 
Hort K (1997), On price formation and quantity adjustment in Swedish housing market, Economic Studies 34, Department of Economics. Uppsala University.

Kosekela E, H Loikkanen and M Virén (1992), "House prices, household savings, and financial market liberalisation in Finland", European Economic Review, 36, 549-58.

Muellbauer J och A Murphy (1997), "Booms and bust in the UK housing market", The Economic Journal, 107, 1701-27.

Poterba J M (1984), 'Tax subsidies to owner-occupied housing. An asset-market approach", The Quarterly Journal of Economics, 99, 729-52.

\section{Appendix}

Tabell A1 Granger (bivariata) kausalitetstest för real prisutveckling för småhus för Stockholmsregionen och ett antal makrovariabler, med längd på variablernas tidseftersläpning från 1, 3, 6, 9 och 12 månader. Redovisad statistika är p-värden av log likelihood ratio test

1 månads tidseftersläpning

\begin{tabular}{|c|c|c|c|c|c|c|c|c|c|c|c|c|c|}
\hline & \multicolumn{4}{|c|}{ Relativ (real)12 mån. förändring } & \multicolumn{3}{|c|}{$\begin{array}{l}12 \text { mån. (real) föränd- } \\
\text { ring }\end{array}$} & \multirow{2}{*}{$\begin{array}{c}\text { Ter- } \\
\text { mins } \\
\text { premie }\end{array}$} & \multicolumn{5}{|c|}{ Relativ 12 mån. (real) förändring } \\
\hline & $\begin{array}{l}\text { Hus- } \\
\text { pris }\end{array}$ & $\begin{array}{l}\text { Nya } \\
\text { order }\end{array}$ & $\begin{array}{l}\text { Ind. } \\
\text { prod. }\end{array}$ & $\begin{array}{l}\text { Nybils- } \\
\text { reg. }\end{array}$ & $\begin{array}{l}\text { Arb. } \\
\text { Löshet }\end{array}$ & $\begin{array}{c}3 \text { mån } \\
\text { ränta }\end{array}$ & $\begin{array}{l}5 \text { års } \\
\text { ränta }\end{array}$ & & M0 & M3 & AFGX & Bokost & Köp \\
\hline & 1 & 2 & 3 & 4 & 5 & 6 & 7 & 8 & 9 & 10 & 11 & 12 & 13 \\
\hline 1 & & 0.415 & 0.316 & 0.250 & 0.006 & 0.059 & 0.019 & 0.009 & 0.828 & 0.282 & 38 & 0.122 & 0.053 \\
\hline 2 & 0.216 & & 0.087 & 0.000 & 0.162 & 0.235 & 0.122 & 0.000 & 0.693 & 0.012 & 0.278 & 0.243 & 0.986 \\
\hline 3 & 0.544 & 0.001 & & 0.042 & 0.006 & 0.011 & 0.014 & 0.022 & 0.176 & 0.001 & 0.080 & 0.687 & 0.330 \\
\hline 4 & 0.006 & 0.001 & 0.014 & & 0.022 & 0.254 & 0.231 & 0.008 & .030 & 0.364 & & 0.092 & 0.070 \\
\hline 5 & 0.455 & 0.626 & 0.193 & 0.194 & & 0.129 & 0.023 & 0.047 & 0.568 & 0.320 & 45 & 0.374 & 0.040 \\
\hline 6 & 0.001 & 0.000 & 0.118 & 0.019 & 0.373 & & 0.910 & 0.070 & 0.001 & 0.040 & 0.405 & 0.000 & 0.006 \\
\hline 7 & 0.003 & 0.271 & 0.990 & 0.023 & 0.593 & 0.040 & & 0.429 & 0.002 & 0.000 & 0.286 & 0.011 & 0.020 \\
\hline 8 & 0.009 & 0.000 & 0.022 & 0.008 & 0.047 & 0.070 & 0.429 & & 0.162 & 0.730 & & 0.397 & 0.796 \\
\hline 9 & 0.009 & 0.005 & 0.205 & 0.000 & 0.040 & 0.003 & 0.000 & 0.162 & & 0.123 & 0.010 & 0.131 & 0.005 \\
\hline 10 & 0.012 & 0.358 & 0.922 & 0.002 & 0.758 & 0.965 & 0.015 & 0.730 & 0.038 & & 0.586 & 0.305 & 0.140 \\
\hline 11 & 0.044 & 0.025 & 0.056 & 0.004 & 0.035 & 0.105 & 0.755 & 0.595 & 0.001 & 0.174 & & 0.000 & 0.194 \\
\hline 12 & 0.017 & 0.000 & 0.006 & 0.007 & 0.007 & 0.525 & 0.245 & 0.397 & 0.585 & 0.400 & 0.747 & & 0.702 \\
\hline 13 & 0.260 & 0.969 & 0.162 & 0.692 & 0.944 & 0.745 & 0.123 & 0.796 & 0.001 & 0.094 & 0.029 & 0.505 & \\
\hline
\end{tabular}


3 månaders tidseftersläpning

\begin{tabular}{|c|c|c|c|c|c|c|c|c|c|c|c|c|c|}
\hline & \multicolumn{4}{|c|}{ Relativ (real)12 mån. förändring } & \multicolumn{3}{|c|}{$\begin{array}{l}12 \text { mån. (real) föränd- } \\
\text { ring }\end{array}$} & \multirow{2}{*}{$\begin{array}{l}\text { Ter- } \\
\text { mins } \\
\text { premie }\end{array}$} & \multicolumn{5}{|c|}{ Relativ 12 mån. (real) förändring } \\
\hline & $\begin{array}{l}\text { Hus- } \\
\text { pris }\end{array}$ & $\begin{array}{l}\text { Nya } \\
\text { order }\end{array}$ & $\begin{array}{l}\text { Ind. } \\
\text { prod. }\end{array}$ & $\begin{array}{l}\text { Nybils- } \\
\text { reg. }\end{array}$ & $\begin{array}{l}\text { Arb. } \\
\text { Löshet }\end{array}$ & $\begin{array}{c}3 \text { mån } \\
\text { ränta }\end{array}$ & $\begin{array}{l}5 \text { års } \\
\text { ränta }\end{array}$ & & M0 & M3 & AFGX & Bokost & Köр \\
\hline & 1 & 2 & 3 & 4 & 5 & & & 8 & & & & & 13 \\
\hline 1 & & & 0.855 & & 0.1 & 0.15 & & 0.019 & 0.977 & & & & 00 \\
\hline 2 & 0.041 & & & & & & & 1 & & & & & 207 \\
\hline 3 & 0.06 & 229 & & & & & & 077 & & & & & .066 \\
\hline 4 & 0.00 & 001 & 0.048 & & 000 & 0 & & 0.078 & 390 & 9 & & & 0.002 \\
\hline 5 & & & 0 & 0.641 & & .012 & & 0.310 & 7 & & & & 0.286 \\
\hline 6 & 0 & 002 & 006 & 014 & 0.011 & & 0.994 & 0.107 & 000 & 22 & & 000 & .010 \\
\hline 7 & & & 614 & & 0.004 & 0.024 & & 0.806 & 0.000 & 00 & & 000 & 0.003 \\
\hline 8 & & & 077 & & 0.310 & 0.107 & 0.806 & & 0.358 & 599 & & & 0.819 \\
\hline 9 & & & 0 & & 0 & 0 . & 0.01 & 0.358 & & 0.030 & & & 0.000 \\
\hline 1( & & & 0 & & 0 & 0. & & 0.599 & 0.042 & & 0.481 & 032 & 0.000 \\
\hline 1$]$ & & & & & & 0.022 & & 0.348 & 0.001 & 0.202 & & 0.009 & 0.007 \\
\hline 12 & 0 & & & & 00 & 0.493 & 0.73 & 0.310 & 0.076 & 0.732 & 0.8 & & 0.214 \\
\hline 13 & 0.003 & 0.291 & 0.262 & 0.000 & 0.006 & 0.681 & 0.088 & 0.819 & 0.000 & 0.165 & 0.070 & 0.696 & \\
\hline
\end{tabular}

6 månaders tidseftersläpning

\begin{tabular}{|c|c|c|c|c|c|c|c|c|c|c|c|c|c|}
\hline & \multicolumn{4}{|c|}{ Relativ (real)12 mån. förändring } & \multicolumn{3}{|c|}{$\begin{array}{l}12 \text { mån. (real) föränd- } \\
\text { ring }\end{array}$} & \multirow{2}{*}{$\begin{array}{c}\text { Ter- } \\
\text { mins } \\
\text { premie }\end{array}$} & \multicolumn{5}{|c|}{ Relativ 12 mån. (real) förändring } \\
\hline & $\begin{array}{l}\text { Hus- } \\
\text { pris }\end{array}$ & $\begin{array}{l}\text { Nya } \\
\text { order }\end{array}$ & $\begin{array}{l}\text { Ind. } \\
\text { prod. }\end{array}$ & $\begin{array}{l}\text { Nybils- } \\
\text { reg. }\end{array}$ & $\begin{array}{l}\text { Arb. } \\
\text { Löshet }\end{array}$ & $\begin{array}{c}3 \text { mån } \\
\text { ränta }\end{array}$ & $\begin{array}{l}5 \text { års } \\
\text { ränta }\end{array}$ & & M0 & M3 & AFGX & Bokost & Кӧр \\
\hline & 1 & 2 & 3 & & 5 & 6 & 7 & 8 & 9 & & 11 & 12 & 13 \\
\hline 1 & & & 0.035 & & & & & & & & & & 0.433 \\
\hline 2 & 0.385 & & & & & & & & & & & & .321 \\
\hline 3 & & 0.221 & & & & & & & & & & & 0.059 \\
\hline 4 & & 6 & 0.104 & & 0.00 & & & & & & & & 0.030 \\
\hline & & & & & & & & 117 & & & & & 0.583 \\
\hline & & & & & 0.006 & & 3 & 0.189 & & & & & 0.008 \\
\hline 7 & & & & & 0.276 & 0.00 & & 0.911 & 12 & & & & 0.023 \\
\hline & & & & & & & 0.911 & & 0.113 & 8 & & & 0.43 \\
\hline & & & & & & & 0.746 & 0.113 & & 0.271 & & & 0.000 \\
\hline & & & & & & & & 0.898 & 0.1 & & 0.372 & & 0.002 \\
\hline & & & & & & & & 0.353 & 0.009 & 0.372 & & 0.007 & 0.012 \\
\hline & & & & & & & & & & & 0.350 & & 0.099 \\
\hline 13 & 0.022 & 0.208 & 0.089 & 0.000 & 0.035 & 0.229 & 0.147 & 0.438 & 0.010 & 0.020 & 0.169 & 0.682 & \\
\hline
\end{tabular}




\begin{tabular}{|c|c|c|c|c|c|c|c|c|c|c|c|c|c|}
\hline & \multicolumn{4}{|c|}{ Relativ (real)12 mån. förändring } & \multicolumn{3}{|c|}{$\begin{array}{l}12 \text { mån. (real) föränd- } \\
\text { ring }\end{array}$} & \multirow{2}{*}{$\begin{array}{l}\text { Ter- } \\
\text { mins } \\
\text { premie }\end{array}$} & \multicolumn{5}{|c|}{ Relativ 12 mån. (real) förändring } \\
\hline & $\begin{array}{l}\text { Hus- } \\
\text { pris }\end{array}$ & $\begin{array}{l}\text { Nya } \\
\text { order }\end{array}$ & $\begin{array}{l}\text { Ind. } \\
\text { prod. }\end{array}$ & $\begin{array}{l}\text { Nybils- } \\
\text { reg. }\end{array}$ & $\begin{array}{l}\text { Arb. } \\
\text { Löshet }\end{array}$ & $\begin{array}{c}3 \text { mån } \\
\text { ränta }\end{array}$ & $\begin{array}{l}5 \text { års } \\
\text { ränta }\end{array}$ & & M0 & M3 & AFGX & Bokost & Köр \\
\hline & 1 & 2 & 3 & 4 & & & & 8 & & & & & 13 \\
\hline 1 & & & 0.021 & & 0.000 & 0.224 & 00 & 0.612 & & & & & 78 \\
\hline 2 & 0.867 & & & & & & & U. & & & & & 2 \\
\hline 3 & 0.00 & .044 & & & & & & 0.21 & & & & & 109 \\
\hline 4 & 0.064 & .005 & 0.010 & & 020 & 91 & & 0.126 & 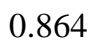 & & & & .278 \\
\hline 5 & 0 & & 0 & 0.508 & & .025 & & 0.10 & & & & & .820 \\
\hline 6 & 0 & 000 & 016 & 001 & 0.000 & & 0.101 & 0.438 & 000 & 0 & 421 & & .056 \\
\hline 7 & 0 & & 496 & & 0.554 & 0.002 & & 0.117 & 0.005 & 0 & 23 & 000 & .025 \\
\hline 8 & & & 215 & & 0.10 & 0.438 & 0.117 & & 0.117 & 0 & & 775 & 0.720 \\
\hline 9 & & & & & 0.29 & 0.010 & 0.41 & 0.117 & & 0.295 & & & 0.000 \\
\hline 1( & & & & & 0.93 & 0.9 & & 0.945 & 0.334 & & 0.421 & 119 & 0.036 \\
\hline 1. & & & & & 018 & & & 0.168 & 0.066 & 0.0 & & 0.012 & 0.001 \\
\hline 12 & 0 & 070 & & & 000 & 0.295 & & 0.775 & 0.214 & 0.969 & 0.0 & & 0.064 \\
\hline 13 & 0.013 & 0.074 & 0.002 & 0.000 & 0.156 & 0.061 & 0.021 & 0.720 & 0.112 & 0.008 & 0.040 & 0.243 & \\
\hline
\end{tabular}

\section{2 månaders tidseftersläpning}

\begin{tabular}{|c|c|c|c|c|c|c|c|c|c|c|c|c|c|}
\hline & \multicolumn{4}{|c|}{ Relativ (real)12 mån. förändring } & \multicolumn{3}{|c|}{$\begin{array}{l}12 \text { mån. (real) föränd- } \\
\text { ring }\end{array}$} & $\begin{array}{l}\text { Ter- } \\
\text { mins }\end{array}$ & \multicolumn{5}{|c|}{ Relativ 12 mån. (real) förändring } \\
\hline & $\begin{array}{l}\text { Hus- } \\
\text { pris }\end{array}$ & $\begin{array}{l}\text { Nya } \\
\text { order }\end{array}$ & $\begin{array}{l}\text { Ind. } \\
\text { prod. }\end{array}$ & Nybils- & $\begin{array}{l}\text { Arb. } \\
\text { Löshet }\end{array}$ & & $\begin{array}{l}5 \text { års } \\
\text { ränta }\end{array}$ & & M0 & M3 & AFGX & Bokost & Köр \\
\hline & 1 & 2 & 3 & 4 & 5 & 6 & 7 & 8 & 9 & & & 1 & 13 \\
\hline 1 & & 0.012 & 0.051 & 0.371 & 0.000 & 0.427 & 0.128 & 0.916 & 0.329 & 0.891 & 0.02 & 478 & 0.165 \\
\hline 2 & 0.900 & & & & 188 & 0.004 & 0.037 & 059 & 186 & 005 & 0.060 & 598 & 0.637 \\
\hline 3 & 0.007 & 0.302 & & & 0.065 & 0.310 & 0.005 & 225 & 136 & 000 & 4 & 317 & 0.308 \\
\hline 4 & 067 & 012 & 0.014 & & 0.069 & 0.927 & 0.603 & 020 & 224 & 136 & & & 0.649 \\
\hline 5 & 037 & & 006 & 0.087 & & 0.063 & 0.092 & 059 & 847 & 4 & & & 0.187 \\
\hline & 00 & & 0 & 09 & 0.001 & & 0.013 & 0.002 & 004 & & & & 0.375 \\
\hline & 00 & 00 & 059 & 068 & 0.394 & 0.000 & & 0.071 & .012 & 0.001 & & 000 & 0.190 \\
\hline 8 & 916 & 059 & 0.225 & 020 & 0.059 & 0.002 & 0.071 & & 0.002 & 0.688 & 4 & 418 & 0.215 \\
\hline 9 & 02 & 28 & 0 & & 0.447 & 0.001 & 0.044 & 0.002 & & 0.035 & 0.0 & . 000. & 0.000 \\
\hline 1( & 17 & & 0 & & 0.750 & 0.955 & 0.029 & 0.688 & 0.401 & & 0.18 & 1 & 0.178 \\
\hline 11 & 30 & & 0 & & 0.017 & 0.093 & 0.089 & 0.014 & 0.158 & & & .138 & 0.036 \\
\hline 12 & 318 & & 022 & & 0.007 & 0.000 & 0.000 & 0.418 & 0.138 & 0.642 & 0.0 & & 0.103 \\
\hline 13 & 0.002 & 0.068 & 0.001 & 0.000 & 0.262 & 0.199 & 0.002 & 0.215 & 0.014 & 0.002 & 0.041 & 0.326 & \\
\hline
\end{tabular}


Tabell A2 Parameterestimat för VAR-modellen, 1982:6-97:7

\begin{tabular}{|c|c|c|c|}
\hline Sthlmpris(-1) & $\begin{array}{c}\text { Sthlmpris } \\
0.56 \\
(7.00)\end{array}$ & $\begin{array}{c}\text { Nybilreg } \\
-0.22 \\
(0.54)\end{array}$ & $\begin{array}{c}\text { Arbetslöshet } \\
-0.64 \\
(-0.69)\end{array}$ \\
\hline Sthlmpris(-2) & $\begin{array}{c}0.21 \\
(2.35)\end{array}$ & $\begin{array}{c}0.22 \\
(0.48)\end{array}$ & $\begin{array}{l}-0.03 \\
(-0.03)\end{array}$ \\
\hline Sthlmpris(-3) & $\begin{array}{c}0.20 \\
(2.21)\end{array}$ & $\begin{array}{r}0.69 \\
(1.52)\end{array}$ & $\begin{array}{l}-2.83 \\
(-2.74)\end{array}$ \\
\hline Sthlmpris(-4) & $\begin{array}{c}0.19 \\
(2.15)\end{array}$ & $\begin{array}{l}-0.19 \\
(-0.41)\end{array}$ & $\begin{array}{c}1.99 \\
(1.90)\end{array}$ \\
\hline Sthlmpris(-5) & $\begin{array}{l}-0.21 \\
(-2.66)\end{array}$ & $\begin{array}{l}-0.62 \\
(-1.51)\end{array}$ & $\begin{array}{c}0.83 \\
(0.89)\end{array}$ \\
\hline Nybilreg(-1) & $\begin{array}{c}0.03 \\
(1.99)\end{array}$ & $\begin{array}{c}0.38 \\
(4.79)\end{array}$ & $\begin{array}{l}-0.10 \\
(-0.58)\end{array}$ \\
\hline Nybilreg(-2) & $\begin{array}{c}0.01 \\
(0.85)\end{array}$ & $\begin{array}{c}0.12 \\
(1.44)\end{array}$ & $\begin{array}{c}0.52 \\
(2.69)\end{array}$ \\
\hline Nybilreg(-3) & $\begin{array}{l}-0.03 \\
(-2.10)\end{array}$ & $\begin{array}{c}0.07 \\
(0.76)\end{array}$ & $\begin{array}{l}-0.15 \\
(-0.79)\end{array}$ \\
\hline Nybilreg(-4) & $\begin{array}{c}0.00 \\
(0.10)\end{array}$ & $\begin{array}{l}-0.03 \\
(-0.38)\end{array}$ & $\begin{array}{l}-0.35 \\
(-1.85)\end{array}$ \\
\hline Nybilreg(-5) & $\begin{array}{r}0.00 \\
(0.26)\end{array}$ & $\begin{array}{r}0.13 \\
(1.56)\end{array}$ & $\begin{array}{l}-0.12 \\
(-0.66)\end{array}$ \\
\hline Arbetslöshet(-1) & $\begin{array}{c}0.00 \\
(0.20)\end{array}$ & $\begin{array}{c}0.00 \\
(0.13)\end{array}$ & $\begin{array}{r}0.52 \\
(6.50)\end{array}$ \\
\hline Arbetslöshet(-2) & $\begin{array}{r}0.00 \\
(0.20)\end{array}$ & $\begin{array}{l}-0.02 \\
(-0.59)\end{array}$ & $\begin{array}{c}0.23 \\
(2.72)\end{array}$ \\
\hline Arbetslöshet(-3) & $\begin{array}{r}0.00 \\
(0.51)\end{array}$ & $\begin{array}{c}0.01 \\
(0.22)\end{array}$ & $\begin{array}{r}0.37 \\
(4.54)\end{array}$ \\
\hline Arbetslöshet(-4) & $\begin{array}{r}0.02 \\
(2.21)\end{array}$ & $\begin{array}{c}0.03 \\
(0.81)\end{array}$ & $\begin{array}{l}-0.24 \\
(-2.90)\end{array}$ \\
\hline Arbetslöshet(-5) & $\begin{array}{l}-0.01 \\
(-1.63)\end{array}$ & $\begin{array}{l}-0.02 \\
(-0.72)\end{array}$ & $\begin{array}{c}0.02 \\
(0.28)\end{array}$ \\
\hline Konstant & $\begin{array}{r}0.00 \\
(1.00)\end{array}$ & $\begin{array}{l}-0.01 \\
(-0.57)\end{array}$ & $\begin{array}{c}0.10 \\
(2.88)\end{array}$ \\
\hline Kort realränta efter skatt(-1) & $\begin{array}{l}-0.01 \\
(-1.77)\end{array}$ & $\begin{array}{l}-0.13 \\
(-3.02)\end{array}$ & $\begin{array}{r}0.11 \\
(-1.13)\end{array}$ \\
\hline Kort realränta efter skatt(-2) & $\begin{array}{r}0.02 \\
(1.62)\end{array}$ & $\begin{array}{r}0.16 \\
(3.24)\end{array}$ & $\begin{array}{l}-0.26 \\
(-2.42)\end{array}$ \\
\hline Kort realränta efter skatt $(-3)$ & $\begin{array}{c}0.01 \\
(1.29)\end{array}$ & $\begin{array}{r}0.08 \\
(1.73)\end{array}$ & $\begin{array}{l}-0.01 \\
(-0.09)\end{array}$ \\
\hline Terminspremie(-1) & $\begin{array}{r}0.00 \\
(0.56)\end{array}$ & $\begin{array}{l}-0.01 \\
(-0.55)\end{array}$ & $\begin{array}{c}0.03 \\
(0.83)\end{array}$ \\
\hline Terminspremie(-2) & $\begin{array}{r}0.00 \\
(-0.86)\end{array}$ & $\begin{array}{r}0.02 \\
(1.67)\end{array}$ & $\begin{array}{c}0.01 \\
(0.35)\end{array}$ \\
\hline $\operatorname{AFGX}(-1)$ & $\begin{array}{l}-0.02 \\
(-1.12)\end{array}$ & $\begin{array}{l}-0.02 \\
(-0.21)\end{array}$ & $\begin{array}{c}0.18 \\
(0.80)\end{array}$ \\
\hline $\operatorname{AFGX}(-2)$ & $\begin{array}{r}0.02 \\
(0.80)\end{array}$ & $\begin{array}{c}0.10 \\
(0.70)\end{array}$ & $\begin{array}{c}0.01 \\
(0.04)\end{array}$ \\
\hline $\operatorname{AFGX}(-3)$ & $\begin{array}{r}0.01 \\
(-0.52)\end{array}$ & $\begin{array}{l}-0.05 \\
(-0.45)\end{array}$ & $\begin{array}{l}-0.34 \\
(-1.48)\end{array}$ \\
\hline Nya order & $\begin{array}{l}-0.01 \\
(-0.15)\end{array}$ & $\begin{array}{l}-0.08 \\
(-0.44)\end{array}$ & $\begin{array}{l}-0.91 \\
(-2.09)\end{array}$ \\
\hline Nya order(-1) & $\begin{array}{l}-0.01 \\
(-0.39)\end{array}$ & $\begin{array}{r}0.25 \\
(1.32)\end{array}$ & $\begin{array}{r}0.24 \\
(0.57)\end{array}$ \\
\hline Adj. R-squared & 0.9430 & 0.6127 & 0.9145 \\
\hline
\end{tabular}

